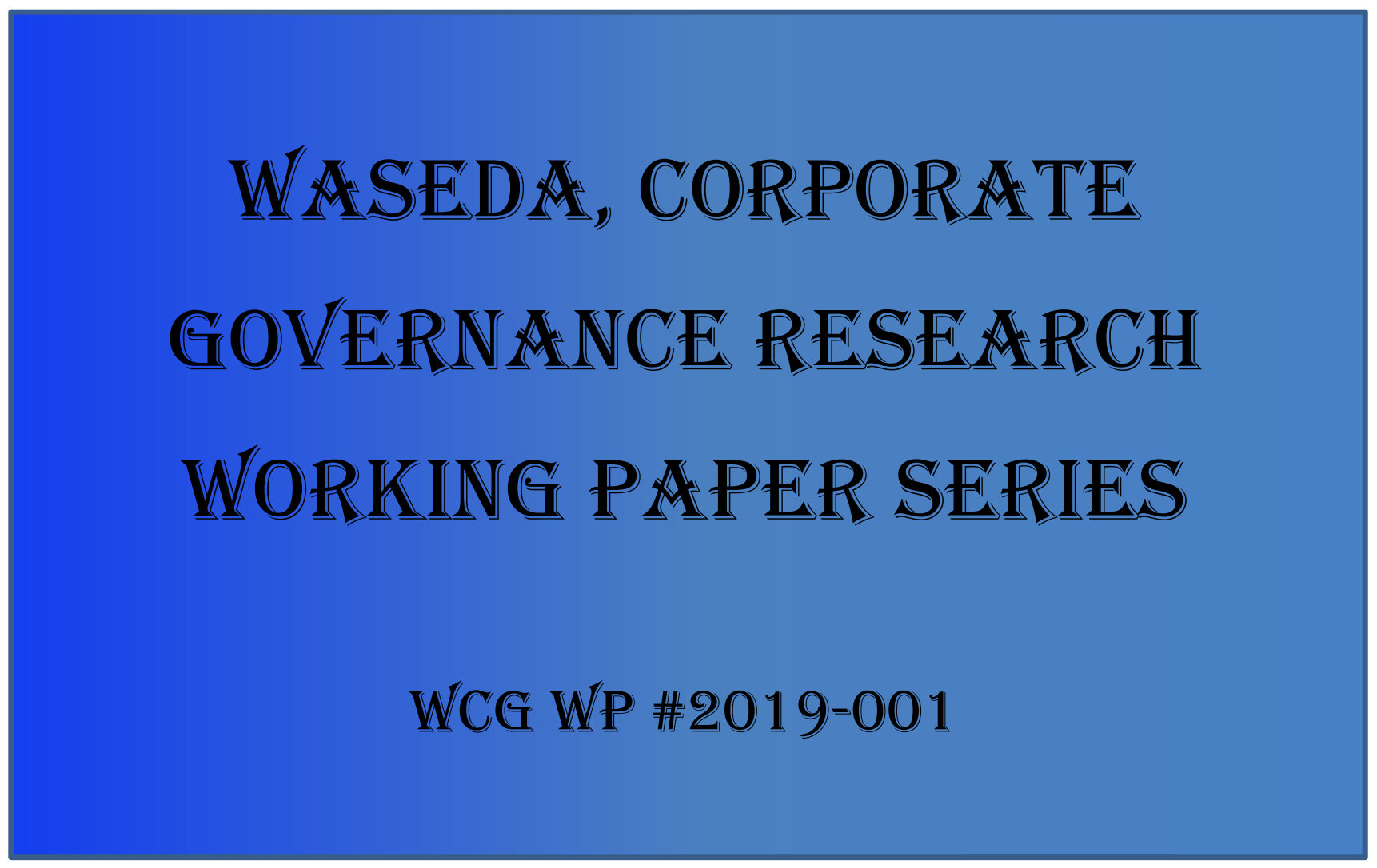

Corporate Governance Reforms under the Abenomics : the Economic Consequences of Two Codes

Hideaki Miyajima (Waseda University)

Takuji Saito (Keio University)

JSPS Core-to-Core Program

Waseda Institute for Advanced Studies

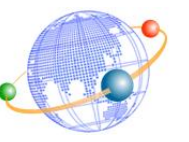




\section{ABOUT JSPS CORE-TO-CORE PROGRAM}

This work was supported by "Core-to-Core Program, A. Advanced Research Networks" of Japan Society for the Promotion of Science (JSPS).

The main objectives of "Core-to-Core Program" are to create world-class research hubs in the research fields, and to foster young researchers through building sustainable collaborative relations among research/education institutions in Japan and around the world.

As a research hub in Japan for the project titled "Creation of a Research Hub for Empirical Analysis on the Evolving Diversity of Corporate Governance: Multidisciplinary Approach Combining Economics, Legal Studies and Political Science" which was selected for "Core-to-Core Program", Waseda Institute for Advanced Studies (WIAS) works together with its overseas counterparts: University of Oxford (UK), Ecole des Hautes Etudes en Sciences Sociales (EHESS) (France), University of British Columbia (UBC) (Canada). Through strengthening the research networks, developing analysis methods, adopting a multifaceted international approach and promoting the joint use of basic data, this project aims to achieve remarkable advancements in empirical analysis of the economic systems associated with corporate governance. 


\title{
Corporate Governance Reforms under the Abenomics : the Economic Consequences of Two Codes
}

\author{
Hideaki Miyajima \\ (Waseda University, RIETI, and WIAS) \\ Takuji Saito \\ (School of Business Administration, Keio University)
}

October 19, 2019

Earlier version of this paper was presented at Stanford University, Yonsei University, SASE Annual Meeting, Hitotsubashi University, RIETI, John Hopkins University, Japan Association for Applied Economics, and Waseda University. We would like to thank Johan Jidinger for outstanding assistance with this project. In compiling the data for this research, we were supported by a KAKENHI research grant (I5H01958, 19H00603, 17K03810) from the Ministry of Education, Culture, Sports, Science and Technology. We were also supported by the JSPS Core-to-Core Program (A. Advanced Research Networks). 


\section{Introduction}

Abenomics advanced a policy mix of bold monetary policy, flexible fiscal policy, and a growth strategy for stimulating private investment, which were called the "three arrows." Corporate governance reforms were positioned as one of the most important issues for the growth strategy, the third arrow. Policy measures to achieve growth through corporate governance reforms are not unique to Abenomics. The pursuit of corporate governance reforms from the standpoint of promoting growth became a global trend following the global financial crisis (Kay, 2012; OECD, 2012). However, in United States, the United Kingdom, and continental Europe, the focus of attention was the problem that shareholder pressure was so strong that firms engaged in excessive risk-taking or myopic business practices. ${ }^{1}$ In contrast, the central issue in corporate governance reforms in Japan is that the existing system has made firms take risk-averse or conservative approaches to business management because the influence of shareholder (employee) remain too weak (strong).

The basic idea of Abenomics was to induce greater efficiency in corporate management in the following ways. First, the Japanese Stewardship Code (JSC) encouraged institutional investors to participate in corporate management and actively exercise their voting rights. Second, the Corporate Governance Code (CGC) promoted the appointment of independent outside directors, adoption of a performance-related compensation system, and reduction of relational shareholdings. Third, reforms of corporate governance systems encouraged greater risk-taking by firms.

To what extent did the corporate governance reforms under Abenomics, which centered on the implementation of the two codes, affect corporate governance systems in Japan? These systems had already been changing since the 1997 banking crisis in Japan. Japanese firms were once commonly characterized by the main bank system, cross-shareholding, and boards consisting of internally appointed directors. However, corporate reorganization efforts after the banking crisis separated hybrid firms, which had significantly changed their external

\footnotetext{
${ }^{1}$ At academic conferences, researchers' interest in the problem that pressure from the stock market could shorten the time horizon considered by corporate managers peaked around 1990 (Stein, 1988; Shleifer and Vishny, 1990; Porter, 1990, 1992). Research on such myopic behavior subsequently became less active but has regained attention in recent years. This resurgence reflects shifting interest in this issue in the United States and the United Kingdom.
} 
governance systems, from traditional Japanese firms that retained their old institutional characteristics (Jackson and Miyajima, 2007). ${ }^{2}$ What impact did the reforms under Abenomics have on this evolution of corporate governance?

If the corporate governance reforms promoted changes in corporate governance systems, to what extent did they change Japanese corporate behavior? According to "Japan Revitalization Strategy 2014," which extensively summarizes the plans under Abenomics, the government intended to change the mindset of corporate management by strengthening corporate governance and to enhance mechanisms for supporting aggressive business decisions for winning in global competition. Furthermore, the government expected firms earning high profits to actively utilize them for capital investment, bold business reorganizations, and mergers and acquisitions (M\&A), instead of accumulating retained earnings. ${ }^{3}$ Did the corporate governance reforms, which was supported by two pillars-the JSC and the $\mathrm{CGC}$-contribute as expected to enhance capital efficiency and corporate risk-taking?

This paper aims to provide answers to these questions. To this end, we first examine the effects of introducing the JSC, one of the two pillars of corporate governance reforms. The direct effects of introducing the JSC include greater engagement by asset owners such as the Government Pension Investment Fund (GPIF), strengthened systems for engagement of traditional institutional investors (e.g., trust banks and investment advisory firms), a gradual shift of life insurance companies from being "silent" partners to becoming vocal long-term shareholders, and revitalization of the activity of activist funds. This paper also shows that the institutional investor ownership ratio increased during the reform period (2013-2017), that the increase was relatively large for firms with a small market capitalization and a low institutional investor ownership ratio, and therefore that the variation in ownership structure among firms decreased contrasting to the fact that it had rapidly increased after the banking crisis.

Second, this paper examines changes in boards of directors brought about by the Japanese CGC and the amended Companies Act and analyzes the effects of the changes. Before 2014, it was left to firms to decide whether to appoint outside directors, and only about half of the publicly traded firms had at least one outside directors. However, the number of outside

\footnotetext{
${ }^{2}$ For details, see Aoki et al. (2007), Miyajima (2017), Miyajima et al. (2018).

3 “Japan Revitalization Strategy (Revised) 2014: Challenges toward the Future," p. 5.
} 
directors increased, although not continuously, after the implementation of the CGC. This paper summarizes changes in corporate boards brought about by corporate governance reforms, quantitatively analyzes the effects of these changes on corporate behavior and performance, and discusses the results. This paper insists that appointing outside directors does not necessarily have a general effect but does have a disciplinary effect on management at family-run firms, medium-sized firms, and firms with a low institutional investor ownership ratio.

Third, the CGC was aimed at reducing relational shareholdings by requiring firms to explain the purpose of such shareholding. It is well known that cross-shareholding among firms had drastically diminished as a result of the dissolution of mutual shareholding relationships between firms and banks after the banking crisis, but the practice has steadily persisted, mainly in the form of cross-shareholding among industrial corporations (jigyo hojin) (Miyajima and Kuroki, 2007; Miyajima and Nitta, 2011). The Abe administration intended to put an end to this type of relational shareholding, considering that it decreased capital efficiency and blocked pressure on corporate management from capital markets. In this context, Jidinger and Miyajima (2019) focused on a sample of 200 firms with a high relational shareholding ratio, which are often called "bedrock companies (ganban kigyo)," and analyzed their shareholding behavior around the time of the corporate governance reforms. This paper discusses the result of the analysis and shows that even firms with a high relational shareholding ratio and those whose relational shareholding is mainly in the form of cross-shareholding have gradually sold their relational shareholdings.

Abenomics was aimed at changing firms' conservative business practices and increasing their earning power. In a final analysis, this paper examines how much corporate governance reforms affected corporate behavior, focusing on performance (ROE, ROA, operating profit margin), investment (capital expenditure, R\&D expenditure, M\&A), policy on shareholder returns (dividends and stock buybacks), debt selection (capital structure), and cash and equivalents held.

Corporate performance increased starting in 2013, when Abenomics was implemented, so it is supposed that the corporate governance reforms contributed to some extent to firms' improved performance by promoting disciplined management. However, these effects of the 
reforms were based not on institutional investors' increased influence, but on an increasing institutional investor ownership ratio, and also the size of the effect was small compared with the change in profit margins during the same period. In addition, no results indicate that corporate governance reforms had an effect on "real" investment, such as capital investment, M\&A expenditure, and R\&D expenditure. The association between the institutional investor ownership ratio and real investment had been consistently positive since 2000 , but its magnitude was smaller during the reform period. There is no evidence that the association between the institutional investor ownership ratio and $M \& A$ or $R \& D$ expenditures did not significantly increase after the reforms. Therefore, the corporate governance reforms seem to have stopped short of changing corporate managers' attitudes toward risk and investment.

The corporate governance reforms, however, clearly increased shareholder returns. The association between the institutional investor ownership ratio and the ratio of gross shareholder returns (dividend + repurchase) to shareholders' equity was consistently significant and positive, and the magnitude of the association was much higher (by about 60 percent) in the reform period. The use of increased profits du ring the Abenomics period was not limited to deliver to shareholders. Firms also continued to reduce debt started before the implementation of Abenomics and did not significantly changed following the corporate governance reforms. Increased shareholder returns and debt reduction did not deplete firms' profits, which resulted in the accumulation of cash and equivalents. The association between the institutional investor ownership ratio and the amount of cash and equivalents held was positive in the pre-Abenomics period. During the reform period, this association remained positive and the institutional investor ownership ratio increased by about 1.7 percent.

The rest of this paper is organized as follows. Section 2 summarizes the characteristics of corporate governance reforms under Abenomics. Section 3 analyzes the effects of introducing the JSC, and Section 4 analyzes the effects of introducing the CGC on the appointment of outside directors. The effects of the reforms on relational shareholding are examined in Section 5 , and the extent to which the reforms affected corporate behavior is examined in Section 6. Section 7 concludes the paper. 


\section{Corporate Governance Reforms as a Growth Strategy}

Following the first boom of corporate governance reforms in the early 2000s, progress toward reforms began again" when the Second Abe Cabinet was formed at the end of 2012, replacing the Democratic Party of Japan Cabinet. Since then, corporate governance reforms have been pursued as a growth strategy - the third arrow of Abenomics - and a series of related policies have been implemented.

As part of the Japan Revitalization Strategy of June 2013, the Cabinet announced its aim to promote corporate governance reforms by strengthening the fiduciary duties of institutional investors through the JSC, which was implemented in February 2014. The revised Japan Revitalization Strategy of June 2014 proposed strengthening Japanese corporate governance with a view to "revive the earning power of Japanese firms." Consequently, reforms were rapidly implemented in 2015, with the drafting and enactment of the CGC. That same year, the revised Companies Act came into force. In the revision of the Japan Revitalization Strategy of June 2016, top priority was given to the implementation of effective governance premised on structural reforms. ${ }^{4}$ A brief chronology of these developments is summarized in Table $\mathbf{1 .}$

-- Table 1 about here--

The aim of corporate governance reform package is clearly described in Japan Revitalization Strategy 2014:

It is important to change the mindset of management by strengthening corporate governance and to establish a system in which active management is promoted by introducing the global level of return on equity (ROE) as a performance criterion. In particular, companies that achieve high accounting performance are expected to actively utilize their profit for further investment, active business restructuring, and M\&A, instead of accumulating retained earnings.

\footnotetext{
4 The specific reforms included 1) strengthening of a "pro-active" governance system; 2) promotion of constructive dialogue between firms and investors; and 3) further encouragement of measures to strengthen the management-supporting function of financial institutions, etc.
} 
In this strategy, it was assumed that the conservative behavior of management could be changed by setting ROE as a performance criterion, enhancing shareholder engagement, appointing independent directors, and refining compensation systems. The characteristics of the corporate governance reforms under Abenomics can be summarized as follows.

First, the corporate governance reforms in Japan clearly attempted to rebalance the influence among various corporate stakeholders by strengthening shareholder rights, implicitly acknowledging that the balance had been biased in favor of employees (insiders). Linking corporate governance reforms to corporate growth is a global trend (Kay, 2012; OECD, 2012), but the problems differ by country. In the United States and the United Kingdom, excessive risk-taking induced by performance-related compensation and myopic management due to strong pressure from shareholders are the targets of reform efforts.

Second, to solve various problems in corporate governance, the reforms promoted shareholder engagement, appointment of independent outside directors, and adoption of a performance-related compensation system. In general, strengthening shareholders' rights can lead to a higher likelihood of increasing dividends and shareholder returns at the cost of long-term investment, while closer monitoring of corporate management by shareholders can make managers less likely to take initiatives and enhancing performance-related compensation system can induce corporate managers to manipulate stock prices for their personal gain. However, the adoption of the reforms implies that the benefits of strengthening corporate governance were considered to exceed their costs.

Third, it is important to note that strengthening corporate governance was expected to lead to corporate growth and increased productivity, as part of a mechanism for equally distributing the benefits of increased earnings to the public. Since corporate governance reforms directly increased the proportion of profits allocated to shareholders and corporate managers, wages and incomes would not rise without an increase in the added-value. The key to "equitably distributing the benefits of the reforms to the public" is that corporate growth spurred by increased investment must lead to increased productivity and higher value-added of labor, which must then leader to higher wages and income. A "trickle-down" mechanism was therefore assumed for the distribution of gains to employees. 
Finally, it was agreed to adopt a framework for promoting reforms based not on mandatory regulations requiring firms to adhere to certain types of arrangements but on proposed best practices and the introduction of a "comply or explain" principle. The introduction of mandatory regulations pertaining to corporate governance would have the advantage of compelling the adoption of reforms by firms that need them, but this could possibly have many side effects for firms that do not need such reforms. So, one could argue that an approach that guarantees flexibility for firms while encouraging reforms is superior. This approach also provided a way to resolve the prolonged debate - that has persisted since 2000 - between the administrative authorities who favored mandatory regulations and the business community who opposed to them.

\section{Stewardship Code: Strengthening Engagement}

\subsection{Enforcing Voting Standards, Active Involvement of Asset Owners and Insurance Companies}

The JSC was published in February 2014 and was modeled on the UK Stewardship Code of 2010. The JSC has seven principles, including that institutional investors (1) have a clear policy on voting rights, (2) have a clear policy on managing conflicts of interest, (3) publicly disclose their voting activity, the results of voting activity, and other aspects of fulfilling their stewardship responsibilities. Immediately after the release of the $\mathrm{JSC}_{2} 127$ institutions agreed to comply with it, including the GPIF, the world's largest public pension fund, with the total reaching 214 institutions in $2017 .^{5}$ The implementation of the JSC has led to the following significant changes.

First, asset owners such as pension funds are involved in the engagement process. In Japan, asset owners were less active as there were no active pension funds equivalent to CalPERS (Jacoby, 2007). The JSC required Japanese asset owners to actively monitor financial institutions entrusted with asset management. That most asset owners, particularly the GPIF, agreed to the JSC was an epoch-making change. The GPIF, which does not manage its assets in-house, does not disclose its own voting policies in detail, but it does ask financial

\footnotetext{
${ }^{5}$ Based on materials from the Financial Services Agency.
} 
institutions entrusted with asset management to comply with the JSC and strictly implement stewardship activities. As a result, to get business from the GPIF, it is basically imperative for institutional investors to strictly follow the JSC. Furthermore, in 2017, the GPIF announced its "Voting Principles," which require financial institutions to disclose their voting results for individual proposals in line with the new disclosure policy from the Financial Services Agencies.

The second change was that implementation of the JSC led to institutional investors setting up independent voting divisions as well as strengthening voting standards. On the organizational side, for example, Mitsubishi UFJ Trust Bank established a committee for exercising voting rights within the asset management department. This committee discussed the basic policy on the exercise of voting rights and the policy for voting on individual resolutions, and these were then finalized by the managing director. In addition, to verify the monitoring results, a stewardship committee was organized, with the majority being outside third-party members. ${ }^{6}$

The main standards for the exercise of voting rights, which were strengthened after the implementation of the JSC, are as follows: (1) profitability standards for appointment of directors, (2) governance standards, and (3) standards for payout policies (see Table 2).

Regarding item (1), an advisory organization for exercising the voting right, Institutional Shareholder Services (ISS), announced a new recommendation, which explicitly set capital productivity (ROE) as a proposed standard for the appointment of directors in October 2014, and suggested voting against the top management at companies with a return on equity (ROE) below 5\% over the past five consecutive years. A Japanese investment advisory company introduced similar standards.

Regarding item (2) on governance arrangements, most institutions set the standard for appointing multiple outside directors. ISS recommended, for example, voting against appointment of a top executive "if the board after the shareholder meeting does not include at least one outsider, regardless of independence.”. Regarding item (3) on payout policy, Daiwa SB Investment Ltd. set the following standard, "for companies with excessive cash, over $50 \%$

\footnotetext{
6 Mitsubishi UFJ Trust "Exercise of stock voting rights in the property trust operation" (http://www.tr.mufg.jp/houjin/jutaku/pdf/unyou kabu 1 pdf.pdf)
} 
of the total profit will be expected to be paid as dividend." In addition, the standards for compensation policy were also clarified. Both foreign and domestic institutional investors indicated their approval for a performance-related compensation system, while opposing retirement benefits such as the so-called one-yen option. Anti-takeover defenses were clearly opposed. Consequently, it is estimated that once the percentage shares held by institutional investors exceeds $62 \%$ on average, introducing anti-takeover defenses would be impossible. ${ }^{7}$

--Table 2 about here -

Third, an important outcome of the JSC is to transform insurance companies from "silent" partners to "long-term shareholders with a voice." declined from $14 \%$ in 1995 , to $11 \%$ in 2004 , and to $5.7 \%$ in 2014 . Also, insurance companies are investing in fewer firms, with a decrease for Nippon Life from 1412 in 2000 to 1014 in 2014, and a decrease for Dai-ichi Life Insurance from 1054 to $501 .^{9}$ Insurance companies reduced their stockholdings evenly at the early phase of the reduction and then took made selective reductions after the mid-2000s. Agreeing to the JSC means that they first disclosed the results of their voting activity. In 2017, Dai-ichi decided to separately disclose their voting results for individual firms. While the ratio of votes against companies' proposals was low, life insurance companies emphasized long-term dialogue with the companies in which they invested, rather than the exercise of their voting right. ${ }^{10}$ According to our interview from a leading insurance company, it engages in dialogue with the core companies (200-300

\footnotetext{
${ }^{7}$ Opposition rate $(Y)$ against takeover defense measures at general shareholders meetings in June 2015 was $Y=90.468+0.6514 X$, whereas $X$ is the ratio of stock ownership of institutional investors (estimation by Nomura Securities).

${ }^{8}$ Focusing on this point, insurance companies were assumed and counted as insiders for the issuing company both in our research as well as in other studies (Franks et al., 2014; Miyajima and Ogawa, 2016).

${ }^{9}$ Miyajima and Suzuki (2018). We counted the number of firms for which the insurance company was listed in the top 30 shareholders.

${ }^{10}$ The average rate of voting against proposals is 5\% for insurance companies compared with $20 \%$ for trust banks and asset management firms (based on materials from the Financial Services Agency).
} 
companies) that it has invested in and examines their responses using several criteria. ${ }^{11}$

The final change associated with the JSC is that various types of institutions participate in the engagement process. In addition to proxy advisory agencies such as ISS and Glass Lewis, Governance for Owners and Hermes Equity Ownership Services act as stewardship agents in dialogue on behalf of fund managers. In addition, focus funds such as Taiho Pacific Partners and Asuka Asset Management Co., Ltd. agreed to the JSC. They invest in a small number of stocks, while engaging in dialogue with the companies on the premise of long-term shareholding. On the other hand, with the support of METI, organizations such as the Investors Management Forum (June 2015) and the Forums of Investors Japan (July 2015) were formed to serve as contact organizations for institutional investors. Thus, in addition to the traditional institutional investors, an interactive engagement system was gradually formed.

\section{Improving the Attractiveness of the Japanese Market}

Corporate governance reforms under Abenomics were expected to improve the attractiveness of the Japanese market through the JSC coupled with reorganization of corporate boards following the implementation of the CGC, which is discussed below. Theoretically speaking, the reforms were expected to mitigate the information asymmetry between foreign institutional investors and publicly traded firms in Japan. In particular, the JSC was expected to increase the institutional investor ownership ratio and strengthen the influence of institutional investors. Let us next examine the extent to which firms' ownership structure changed due to the corporate governance reforms under Abenomics. Table 3 focuses on firms listed on the First Section of the Tokyo Stock Exchange (hereinafter, TSE-1 firms) and shows the institutional investor ownership ratio and the foreign institutional investor ownership ratio.

--Table 3 about here--

First, it should be noted that the institutional investor ownership ratio (simple average) significantly increased from 19.8 percent in 2012 to 27.8 percent in 2017. The latter percentage exceeds the highest percentage observed before the global financial crisis (approximately 23

${ }^{11}$ Questionnaire survey, June 2017. 
percent in 2005 and 2006) by almost 5 percentage points. Of the increase of about 8 percentage points between 2012 and 2017, increased shareholding by foreign institutional investors accounts for 4.7 percentage points, and increased shareholding by domestic institutional investors accounts for 3.3 percentage points. The increased shareholding by domestic institutional investors was due to the increase in stockholding of the GPIF that started in 2015 and due to ETF purchases by the Bank of Japan. These entities commission trust banks and investment advisory firms to purchase shares.

The shares held by these financial institutions in this manner, combined with the other shares they hold, affect their choice of firms for engagement, and the firms issuing these shares become subject to the exercise of voting rights by these financial institutions that follow their voting guidelines. Experts have pointed out that the increased stockholding of the GPIF and the ETF purchases by the Bank of Japan entail problems related to stock pricing and restricted choice in selling shares. However, from the standpoint of corporate governance, these activities clearly strengthen investor engagement. The increase in shareholding by foreign institutional investors can be attributed to heightened trust in the Japanese market resulting from progress made in reform efforts, while the increase (including the dramatic increase in FY 2012) also seems to be attributable to the lower price of Japanese stocks caused by depreciation of the yen.

A second point to note is a decrease in the variation among firms in the institutional investor ownership ratio, particularly, the foreign institutional investor ownership ratio. This stands in contrast to the fact that the variation across different firm sizes increased from 1997 to 2005 (Miyajima and Kuroki, 2007). The behavior of foreign institutional investors is strongly biased as they tend to prefer larger firms, liquidity, and familiarity. As Table $\mathbf{3}$ shows, the average institutional investor ownership ratio and the average foreign institutional investor ownership ratio were 37.2 percent and 25.2 percent, respectively, for the firms in the fifth quintile of market capitalization as of the end of FY 2012. In contrast, the averages are 18.2 percent and 10.5 percent, respectively, for the firms in the third quintile and 6.5 percent and 3.2 percent for the firms in the first quintile. A similar trend was widely observed in the United States and other countries in the 1990s (Gompers and Metrick, 2001). However, as progress was made in corporate governance reforms in Japan, the investment activity of foreign 
institutional investors expanded to include small- and mid-cap stocks. Table 3 shows that increases in the institutional investor ownership ratio (foreign institutional investor ownership ratio) are large among the firms in the second and third quintiles of market capitalization, at 8.6 percent (5.0 percent) and 9.7 percent (6.5 percent), respectively, which are above the overall average of 8.0 percent (4.7 percent). The coefficient of variation (standard deviation / mean) for the foreign institutional investor ownership ratio decreased by about 20 percent, from 0.912 in 2012 to 0.711 in 2017.

As for differences in ownership structure across different firm sizes are large, it is clear that the firms included in the MSCI Japan Index or the JPX-Nikkei 400 (JPX400) index equally face pressure from institutional investors while small and medium-sized firms are subject to less pressure from institutional investors. Corporate governance reforms, however, began to lessen this difference, and small and medium-sized firms that had received little pressure from institutional investors have been increasingly subject to the engagement of these shareholders.

\section{Corporate Governance Code: Board Reforms}

\subsection{Major Aims of the Corporate Governance Code}

The second pillar of corporate governance reforms under Abenomics was the Japanese CGC, which was modeled on the OECD Principles of Corporate Governance. Intensive discussion and drafting on the CGC was started in late 2014 and it was soon adopted in June 2015, reflecting the serious efforts of the Abe Cabinet to move forward on this issue. The CGC comprises 5 general principles, 30 principles, and 38 supplementary principles (a total of 73 items). The 5 general principles are (1) protection of shareholder rights, (2) cooperation with stakeholders, (3) information disclosure and transparency, (4) responsibilities of the board of directors, and (5) dialogue with shareholders ${ }^{12}$.

The CGC includes various items on best practices, ranging from early mailing of proposals to shareholders and sufficient explanation of important capital policies (seasoned equity offerings and management buyouts) to takeover defenses. We focus on the effects of the

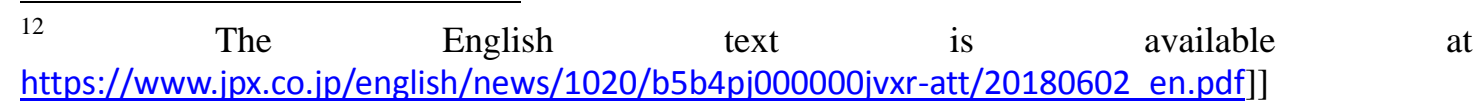


CGC on board design and cross-shareholding, considering that these would have the most significant impact on the essential characteristics of corporate governance among Japanese firms.

\subsection{Appointing Independent Outside Directors and Reorganizing Corporate}

\section{Boards}

Regarding the impact of the CGC, we first examine the extent to which the CGC has changed board structures among Japanese companies. Three points should be noted.

First, Principle 4 of the CGC requires firms to appoint at least two independent directors. If this requirement is not satisfied, then they must provide a sufficient reason for not adopting this practice.

Second, the revised Companies Act made it possible for listed firms to choose the new option of becoming a company with audit and supervisory committee (kansa tou iinkai secchi gaisha), in addition to the conventional system of a company with company auditor (kansa-yaku kai secchi gaisha) and a company with nominating committee, etc (CWNC; shimei iinkai tou secchi gaisha). The aim of this revision of the law is to encourage a shift from the current management boards to monitoring boards for firms, considering that firms felt it was difficult to choose a U.S.-type system of CWNC, where half of the directors must be independent. On the other hand, a hidden motivation of the revision is to allow former outside auditors to become new outsider directors, given the serious shortage of independent directors. Moreover, the CGC recommended establishing informal committees such as a nomination committee and a compensation committee.

Third, Principle 4-10 of the CGC states that when a publicly traded firm adopts the most appropriate organizational design for its characteristics based on specifications in the Companies Act, it should try to further improve its governance systems by utilizing optional mechanisms as needed. The CGC also states that firms should set up, under the board of directors, independent advisory committees, such as nomination and compensation committees, whose main members are independent outside directors. In this way, firms should receive appropriate advice and engagement from independent outside directors in examining particularly important issues such as those related to nominations and compensation. 
Though outside directors had previously been appointed at a slow pace, the measures described above promoted unprecedented appointment of outside directors. As seen in Table 4, Panel A, the average number of outside directors drastically increased from 1.17 in 2012 (before introduction of the CGC) to 2.42 in 2015 (after introduction of the CGC). The proportion of outside directors on corporate boards also jumped from 13.7 percent to 28.3 percent. As Figure 1 shows, the average number of outside directors gradually increased since 2004, but it took 10 years to exceed 1 . The number suddenly rose due to these measures. By 2017, the percentage of firms with at least two outside directors reached 93.4 percent, which shows that most firms complied with the CGC instead of providing explanations for non-compliance.

--Table 4 /Figure 1 about here--

The JPX400 is an index of major firms that have been primary investment targets of overseas institutional investors. The proportion of JPX400 firms with no outside director had already declined to 24 percent by the end of FY 2012. Many of the firms in this group had voluntarily appointed outside directors before the introduction of the CGC because of the strong demand from institutional investors. From a different angle, however, this means that more than 20 percent of these firms maintained an all-insider board of directors at their own discretion, despite pressure from institutional investors. Therefore, another significance of the CGC is that firms that had avoided voluntarily appointing outside directors implemented major reforms around the time of the CGC's introduction.

The case of the Toyota Motor Corporation is a representative example. During the first peak period of corporate governance reforms between 1998 to 2002, the firm intentionally did not appoint outside directors and had an explicit policy of having board members also serve as executive officers. The stated reason was that, in making important decisions, it was essential for the manufacturing firm's board members to have direct knowledge of its workplace, and the firm emphasized that it would address issues involving self-supervision by increasing the number of outside auditors (Inoue, 2004). However, as corporate governance reforms were rapidly advanced by the Abe Cabinet, the firm shifted its policy in March 2013 and appointed 
outside directors for the first time. They were a former vice president of GM, a former chairman of Nippon Life Insurance, and a former bureaucrat. Similar examples were seen at companies such as Canon, FANUC, and Keyence, which were highly competitive in manufacturing. The corporate governance reforms therefore induced firms that had maintained a traditional management board to reorganize their boards of directors.

As of 2018, the proportion of firms that became companies with an audit and supervisory committee (kansa iinkai secchi gaisha) due to the 2015 amendment to the Companies Act was 24 percent, and about a quarter of TSE-1 firms became this type of company. In particular, a number of relatively small firms made the transition. More specifically, 27 percent of non-JPX400 firms made this change, whereas 15 percent of JPX400 firms did so. Even though the introduction of the CGC and other measures brought significant changes to Japanese firms' boards, few firms applied a U.S.-type system of CWNC (companies with nomination, audit, and compensation committees). The proportion of companies with these three committees rose by only 0.4 percentage points between 2013 and 2018. A reason is that firms are very wary of the possibility that outside directors in the nomination committee gain control over important personnel-related decisions.

It should be also noted that a number of firms set up a nomination committee and a compensation committee, which were voluntary, when the CGC was introduced. By 2018, about 30 percent of the TSE-1 firms had a voluntary committee. More than half of JPX400 firms have a voluntary committee. If the statutory nomination committee is also taken into account, about 60 percent of firms have a nomination committee.

As discussed above, Japanese firms' boards of directors significantly changed when the CGC was introduced; however, these boards remain less independent than boards of the firms in other advanced countries such as the United States where the average proportion of independent outside directors on a board of directors is around 70 percent. Therefore, even if firms set up a voluntary committee when the Code was introduced, they did not fully transition from a management board system, in which the board is essentially characterized by its engagement in business management, to a monitoring board system in which the board specializes in supervising management activities. As boards of directors at many firms still function as a management board, the creation of voluntary committees at JPX400 firms with a 
high institutional investor ownership ratio could be interpreted as the fine-tuning of their internal governance systems to adapt to an external change.

\subsection{Effects of Board Reforms}

\section{Appointing Outside Directors}

Did the increase in the number of outside directors following the implementation of the CGC and other policies lead to better management results? The reforms were implemented based on the assumption that there were firms with few outside directors (i.e., firms that should appoint them but had not done so), that the introduction of the CGC would induce such firms to appoint outside directors, and that management policies would subsequently change to improve corporate performance. Fauver et al. (2017) analyzed the effect of board-related reforms in 41 countries and reported that the reforms led to an increase in corporate value, especially in countries that adopted a comply-or-explain rule.

Another scenario can be envisioned, however. Indeed, many Japanese firms voluntarily appointed outside directors suitable for them, meaning that many firms needing to appoint outside directors had already done so. It is therefore possible that the introduction of the CGC has given firms with no need for outside directors no choice but to appoint them. It is also possible that such firms appoint outside directors as a formality, just to comply with the CGC, and do not take advantage of their presence on the board. In both cases, appointing outside directors would not affect management policies or corporate performance. Duchin et al. (2010) show that on average the increase in the number of outside directors intended to comply with the Sarbanes-Oxley Act and listing regulations did not lead to an increase in corporate value or profit.

To examine the validity of the two scenarios, this paper takes advantage of introduction of the CGC and estimates the causal effect of an increased number of outside directors on corporate performance and corporate behavior. It is difficult to accurately ascertain the effects of a corporate governance system on corporate performance due to the reverse causality (i.e., corporate governance affects corporate behavior and performance, while corporate performance affects governance). Furthermore, there is the problem of endogeneity as it is impossible to control for all factors that influence both performance and governance. We use 
difference-in-difference method for overcoming this problem. We assume that the appointment of outside directors following the introduction of the CGC was intended to comply with Principle 4-8, which stipulates that a firm should appoint at least two independent outside directors. In other words, the increase in the number of outside directors was caused not by changes in corporate attributes or other factors, but by an exogenous measure (i.e., a policy). Therefore, estimation of the causal effect of the appointment of outside directors is considered possible by comparing changes in the corporate performance and behavior of firms that did not fulfill the CGC's principle prior to its implementation but subsequently appointed outside directors, with changes in the corporate performance of firms that already fulfilled the principle even before the CGC's implementation.

Based on the idea described above, we analyze a sample of TSE-1 firms in 2013. Specifically, in the analysis the dependent variable is change in corporate performance before and after the introduction of the CGC and the explanatory variables include change in the number of outside directors. To deal with the endogeneity of change in the number of outside directors, a dummy variable is used as instrumental variable that takes a value of 1 if the number of outside directors was less than two before the introduction of the Code and zero otherwise. Approximately 60 percent of firms had less than two outside directors before the introduction of the Code, meaning that they did not fulfill Principle 4-8. About 80 percent of these firms had appointed two or more outside directors as of one period after the introduction of the Code and fulfilled this principle. In fact, at the first stage of analysis, in which the dependent variable is change in the number of outside directors, the coefficient of the dummy variable is approximately 1 and is statistically significant at the 1 percent level.

--Table 5 about here --

Table 5 shows the results of estimating the effects of change in the number of outside directors on corporate performance, taking endogeneity into account (i.e., the results of the second stage). The results do not show that an increase in the number of outside directors led to a statistically significant improvement in performance as measured by ROA, ROE, and Tobin's q. These results seem to suggest that the second scenario is valid. It is possible, however, that 
the effectiveness of outside directors varies depending on corporate attributes. Therefore, analysis is performed including interaction terms (Change in number of outside directors $x$ Firm size (sales); Change in number of outside directors $\times$ Foreign ownership ratio; Change in number of outside directors $\times$ Managerial ownership ratio). The coefficient of the interaction term (Change in number of outside directors $\times$ Foreign ownership ratio) is negative and significant in some estimation models. This result implies that a greater performance improvement follows an increase in the number of outside directors for a firm that has a lower foreign ownership ratio and faces less discipline from capital markets. For example, a 10 percentage point decrease in the foreign ownership ratio is associated with a 0.6 percentage point increase in ROA if the number of outside directors increases by two. The coefficient of the interaction term (Change in number of outside directors $\times$ Managerial ownership ratio) is positive and significant in some estimation models. More specifically, a 10-percentage point increase in the management ownership ratio is associated with a 0.3 percentage point increase in ROA if the number of outside directors increases by two. This result implies that greater performance improvement follows an increase in the number of outside directors for a family-run firm where the founding family has strong managerial control.

As for the increased risk-taking anticipated under Abenomics, on average there is no evidence of an increase in the number of outside directors leading to an increase in capital investment or R\&D expenditure even when corporate attributes are taken into account.

\section{Companies with an Audit and Supervisory Committee and Voluntary Committees}

As discussed above, corporate governance reforms provided an opportunity for appointing outside directors and reorganizing the board of directors. The revision of the Companies Act, which coincided with the implementation of the CGC created a new option (company with an audit and supervisory committee), in addition to the existing options (company with an auditor board (traditional) and company with nomination, audit, and compensation committees [U.S. style]). Also, supplemental principles recommended firms to create voluntary committees such as a nomination committee and a compensation committee.

Approximately a quarter of TSE-1 firms consequently became companies with an audit 
and supervisory committee; however, the results of our analysis do not show that the transition had any obvious effect on corporate behavior or performance. This implies that firms decided to become companies with an audit and supervisory committee to not only improve their corporate governance, but also fulfill a principle of the CGC.

In contrast, the existence of voluntary committees has a substantial impact on corporate governance. According to our estimation, given a 5 percent increase in ROA, executive compensation at a firm with a voluntary compensation committee is 9 percent higher than that at a firm without a compensation committee. This result implies that creation of a compensation committee may lead to a higher proportion of performance-based pay in executive compensation. Also, a firm with a nomination committee is more responsive to corporate performance in terms of changes in management. More specifically, if ROA falls from its average by 5 percent, the probability of the top executive being replaced at a firm with a nomination committee is 1.3 percent higher than that at a firm without a nomination committee. Voluntary committees not only perform their responsibilities, but also potentially affect corporate behavior and performance through improved quality of decisions made by the board of directors and through increased incentives for corporate managers. The result of the relevant estimation shows that creation of a voluntary committee at a firm has a statistically significant effect on its financial policy while it is not sufficiently clear whether creation of a voluntary committee leads to improved corporate performance. The results also show that compared with the situation before creating a voluntary committee, a firm with a voluntary committee has a higher level of shareholder returns (including stock buybacks) and a lower level of cash and equivalents held.

\section{Corporate Governance Reforms and Reduction of Relational Shareholdings}

\subsection{Promoting Sales of Relational Shareholdings}

Principle 1-4 of the CGC demands that firms explain the reason for relational shareholding, as seen in the follows.

Firms should disclose their policy on relational shareholding. Also, each year, the board of 
directors should examine the medium- to long-term economic rationale behind relational shareholding and its future prospects from the standpoint of return and risk and provide a concrete explanation on the purpose and rationality of relational shareholding. Publicly traded firms should set and disclose their standards that are used to guarantee proper exercise of voting rights granted due to relational shareholding.

In June 2015, immediately after the introduction of the CGC, Mizuho Bank announced a further reduction of cross-shareholdings. In the same month, Sumitomo Mitsui Banking and Bank of Tokyo-Mitsubishi UFJ also announced their intention to reduce cross-shareholdings. It is true, however, that the amount of stocks held by banks fell to about 3 percent of stocks held by TSE-1 firms as a result of the rapid decline of cross-shareholding with industrial corporations that started in 2000 (see Figure 2), and three mega banks held stocks worth about 9 trillion yen. In addition, while the three mega banks explicitly showed their intention to reduce the amount of their cross-shareholdings, they had an internal conflict: the finance department wanted to avoid the price volatility of shares, but the loan department was hesitant about selling them as it wanted to maintain good business relationships with borrowers.

--Figure 2 about here--

Relational shareholding consequently started to be mainly conducted between industrial corporations. As the risk of holding stocks increased due to the introduction of mark-to-market accounting, firms that had intensified this type of relational shareholding in the name of strategic cooperation in 2006 to 2008 had to book large impairment losses after the global financial crisis. Also, as institutional investors increasingly demanded efficient use of capital, firms needed to review their relational shareholding. The introduction of the CGC is considered to have provided an opportunity for firms to reexamine whether they should continue their relational shareholding or sell stocks held for relational purposes. ${ }^{13}$

The market positively reacted to firms' reduction of relational shareholding. For example, Yamaha announced after the end of the trading session on November 28, 2017 that it would

${ }^{13}$ In FY 2015, the real value of such sales was around 1.6 trillion yen for the TSE as a whole, and 1,024 firms (47 percent of the listed firms) were considered to have reduced relational shareholdings (Nihon Keizai Shimbun, "One-Trillion-Yen Discontinuation of Cross-Shareholding," August 18, 2016). 
sell 8 million cross-held shares of Yamaha Motor and, at the same time, decided to use the proceeds from the sale to buyback 3.7 percent ( 7 million shares) of Yamaha's outstanding shares, with a spending limit of 25 billion yen. The stock price of Yamaha rose by 7 percent next day as the market positively viewed the firm's improved ROE and shareholder returns. ${ }^{14}$

\subsection{Relational Shareholding in Reality}

Table 6 compares firms in the top quartile of the relational shareholding ratio with those in the bottom quartile, as well as firms in the top quartile of the cross-shareholding ratio with those in the bottom quartile. Firms in the top quartile of both measures on average have lower profitability and lower growth opportunities, smaller market capitalization, lower CAPEX, $R \& D$, and M\&A expenditures, and a lower percentage of foreign ownership.

--Table 6 about here--

This inverse correlation between high relational/cross-shareholding and corporate performance that the Abe Cabinet and other policymakers have paid considerable attention. ${ }^{15}$

Because of reverse causality, the exact causal relationship between high relational/cross-shareholding and low profitability and low growth opportunities is not clear. The decision to sell relational shareholdings is voluntary, so firms with low profitability and low growth opportunities are likely to keep their relational/cross-shareholdings due to their intention to maintain a close relationship with other firms or due to their lack of institutional investors. This is exactly what happened during the 1997-2004 period, when banks rapidly reduced their cross-shareholding (Miyajima and Kuroki, 2007).

However, once ownership structures stabilized after 2006, it is highly plausible that high relational shareholding caused low performance (low ROA, low stock returns, and less active investment. Miyajima and Nitta (2011), Miyajima and Hoda (2015), and Miyajima and Ogawa

\footnotetext{
14 "Yamaha up 7\%: Positive Response to Buyback and End of Cross-Shareholding Relationship" (Nihon Keizai Shimbun, November 29, 2017).

${ }^{15}$ It used to be assumed that cross-shareholding played a positive role in Japanese economic growth. See Aoki (1990), Abeglen and Stark (1985), Flath (1993), and Odagiri (1992).
} 
(2016) reported that high foreign or institutional ownership caused low performance, while Ikeda et al. (2018) found that firms with high cross-shareholding were likely to have had low performance due to enjoying the so-called "quiet life."

\subsection{Reduction of Relational Shareholdings Due to Corporate Governance Reforms}

The JSC states that institutional investors should become actively engaged in managerial decisions of firms in which they hold stocks. Promoting efficient use of capital is one of the main activities in such investor engagement. One of the demands to firms made by recently reinvigorated activist funds was also effective use of capital, including reexamination of relational shareholdings and increased shareholder returns through sale of relational shareholdings.

The CGC as revised in 2015 states that firms should provide reasons for relational shareholding and explain their validity. After the introduction of the CGC, all publicly traded firms explained their reasons for relational shareholding in their corporate governance reports, following Principle 1-4. However, their explanations lack variety as they are quite similar to one another. It should be noted, however, that in response to the CGC's principle that firms should examine the rationality of relational shareholding, the boards of some firms started to regularly consider relevant issues in decision-making. This implies that outside directors started to play a substantial role in making decisions on relational shareholdings.

For capturing a firm's decisions on relational shareholding, it is not appropriate to focus on the accounting information of relational shareholding based on its current value, as it is highly subject to the market fluctuations. Therefore, Jidinger and Miyajima (2019) use the actual number of shares of relational shareholding, which is available from the end of FY 2010, when amendment of information disclosure rules first required firms to disclose details of their relational shareholdings. ${ }^{16}$

In Table 7, row A shows the aggregate number of firms that sold at least one named stock from their relational shareholdings. The percentage of firms that decided to sell increased considerably from $36 \%$ in 2012 before the CGC to 51\% in 2015 and to $89 \%$ in 2017. Row B

${ }^{16}$ The amendment required all listed firms to disclose the following: the name of firms, the number of shares held, and the book and current values of those shares. 
shows the aggregate number of named stocks in relational shareholdings for all 200 companies and those that were sold. A substantial increase in the decision to sell is also observed following the enactment of the CGC in 2015. From 2015 to 2017, the total number of decisions to sell increased from 330 in 2012, to 482 in 2015 , and to 1073 in 2017 . Thus, the probability of a relational shareholding asset being sold increased from 7\% in 2012 to $21 \%$ in 2017.

Lastly, row $\mathrm{C}$ shows the average number of firm decisions in the sample, which is the number of decisions to sell at time $t$ standardized by the number of named stocks held at time $t$ 1. It shows a discontinuous jump in 2015 from the previous level of 2.7 to 3.4 and reaches as high of 5.8 in 2017. The last row shows the total number of shares per firm, which declined from 26.9 million to 21.2 million, roughly a $22 \%$ reduction, following the corporate governance reforms.

--- Table 7 about here ---

In light of these simple descriptive statistics, we posit that the CGC reforms have been effective not only for all listed companies but also implicitly for firms in the top quartile of relational-shareholding (the core of cross-shareholding companies). To better understand the effects, we first estimate the aggregate data that may affect a company's decision to sell relational shareholding.

\subsection{Determinants}

Which stocks did "bedrock companies" sell? Jidinger and Miyajima (2019) focused on these firms, which have a high relational shareholding ratio, and analyzed their annual decisions on selling relational shareholdings by estimating (1) a fixed-effect model in which the dependent variable is the number of firms issuing stocks sold by the bedrock firm each year and (2) a logit model focusing on each individual shareholding relationship, in which the dependent variable indicates sale or continued shareholding for each year.

First, the results of their analysis revealed the following tendencies: a bedrock firm with a higher ratio of relational shareholdings to total assets was more likely to sell; a bedrock firm having smaller latent gains from relational shareholdings was more likely to sell; stocks with 
larger latent gains were sold before those with smaller latent gains; and a bedrock firm with a greater need to secure liquidity by selling shareholdings (i.e., a firm with a higher debt ratio or a lower interest coverage ratio) was more likely to sell. Put simply, the decision on whether to sell relational shareholdings was basically made in a financially rational manner.

Second, the introduction of the CGC has a significant positive relationship with sale of shares both (1) in the analysis where the number of firms issuing the stocks sold by a bedrock firm is the dependent variable and (2) in the analysis of the decision on whether to sell a shareholding in a firm. For example, the estimation results for the first analysis shows that, all things being equal, the introduction of the CGC increased the number of firms issuing stocks sold by a bedrock firm from 2.5 to 3.4 .

Third, the second analysis made it possible to examine the cross-shareholding relationship between two firms and revealed that the existence of a cross-shareholding relationship formed the foundation of relational shareholding. The corporate governance reforms centered on the JSC and CGC induced firms to sell relational shareholdings in other firms despite the existence of cross-shareholding relationships with them.

Lastly, a bedrock firm with a high foreign ownership ratio was less likely to sell relational shareholdings. This result contrasts with the tendency for TSE-1 firms with a higher institutional investor ownership ratio to have, on average, a lower relational shareholding ratio and a lower cross-shareholding ratio. The characteristic of bedrock firms that their relational shareholding ratio is high when the proportion of their shares held by institutional investors is high implies that one of the motivations for relational shareholding is to block pressure from capital markets. The corporate governance reforms have not been effective enough in mitigating this entrenchment effect.

In sum, corporate governance reforms based on a comply-or-explain rule was effective in reducing bedrock firms' relational shareholdings, which had hardly changed previously.

\section{Consequences of Corporate Governance Reforms under Abenomics}

\subsection{Corporate Performance after Corporate Governance Reforms}

As discussed in the previous section, since the start of the Second Abe Cabinet in 2012, 
cross-shareholding has declined, and the institutional investor ownership ratio has increased due to the introduction of the JSC and the CGC. Also, since 2014, dialogue between institutional investors and firms on long-term corporate management and financial policy has become increasingly active as standards regarding institutional investor voting were strengthened and as institutional investor engagement further increased. A question now arises as to whether these changes influenced firms' decision-making and gave rise to the economic virtuous circle envisioned by Abenomics. This section examines this question.

Table 8 shows the performance of TSE-1 firms. From 2012, when the Abe Cabinet was formed, to 2017 , mean ROE increased by 2.8 percentage points from 5.8 to 8.6 percent, and median ROE increased by 2.4 percentage points. Also, mean and median ROE in 2017 exceeded values before the global financial crisis by 1.6 and 1.3 percentage points, respectively. To examine what caused this increase, ROE was decomposed into net profit margin (net profit / sales), total asset turnover (sales / total assets), and financial leverage (total assets / equity). Mean and median net profit margin increased by 1.9 and 1.4 percentage points, respectively, between 2012 and 2017, which contributed to the increase in ROE. A similar tendency is observed for the operating profit margin (note: operating profit is not affected by non-operating profit or loss, or by extraordinary profit or loss). In contrast, both mean and median total asset turnover fell by 0.04 between 2012 and 2017, which lessened the increase in ROE. Similarly, mean and median financial leverage decreased by 0.29 and 0.12 , respectively, also lessening the increase in ROE. These results show that the increase in ROE between 2012 and 2017 is attributable to improved profitability, but not to increased asset efficiency or use of debt.

--- Table 8 about here ---

ROA exhibits a similar pattern: Over the period from 2012 to 2017, mean ROA increased by 1.1 percentage points from 6.4 to 7.5 percent, and median ROA increased by 1.3 percentage points. As mentioned above, total asset turnover decreased during the same period. Therefore, the increase in ROA is solely attributable to an increase in profit margins.

How were increased profits used? Contrary to what was anticipated under Abenomics, investment did not markedly increase. From 2012 to 2017, the mean of the ratio of capital 
expenditure to physical fixed assets increased by only 1.2 percentage points from 16.0 to 17.2 percent, and its median increased by only 0.8 percentage points. Over the same period, the mean $R \& D$ intensity ( $R \& D$ expenditure / sales) decreased by 0.2 percentage points from 2.7 to 2.5 percent, and its median also fell by 0.2 percentage points. While the mean of a measure of cash acquisitions of firms (total acquisition / total assets) increased by 0.1 percentage points from 0.3 to 0.4 percent, its median was zero. This shows that most firms do not engage in corporate acquisition, and some large acquisitions (cross-border M\&A) seems to have driven mean values.

Payout for shareholders showed a statistically significant increase during the Abenomics period. From 2012 to 2017, the mean ratio of total annual dividends to equity rose 0.5 percentage points from 1.9 to 2.4 percent, and its median rose 0.4 percentage points. Also, the mean ratio of total annual dividends plus stock buybacks to equity increased 0.7 percentage points from 2.4 to 3.1 percent, and its median increased by 0.5 percentage points. The increase in this ratio accounts for about a quarter of the increase in ROE, which shows that a major part of the profit increase was used for dividends and stock buybacks.

Not all the profit increase was used for dividends. Some of it was used to reduce debt, and the rest was held by firms as retained earnings. The mean cash and equivalents ratio ([cash and equivalents + securities] / [total assets - cash and equivalents - securities]) increased by 2.8 percentage points from 27.2 to 31.1 percent, and its median increased by 3.0 percentage points.

Taken together, these results show that after the start of the Abe administration in 2012, firms' earning creation increased due to depreciation of the yen, corporate tax cuts, and other factors, and ROE rose mainly because of firms' improved profitability. The increased profit led to increased shareholder returns, but not to increased investment. Therefore, the amount of cash held by firms increased in 2013 and continued to do so in subsequent years, contrary to what was anticipated under Abenomics.

\subsection{Effects of Corporate Governance Reforms}

How are the changes described above related to corporate governance reforms? The following simple model is estimated, taking into account the fact that the reforms sought to change corporate behavior by strengthening shareholders' authority. 


$$
P_{i, t}=F\left(I N S T_{i, t}, J S C, I N S T^{*} J S C 、 X_{i, t}, Y_{t}\right)
$$

$P_{i, t}$ is a variable that measures corporate performance or behavior. ROE, ROA, and the operating profit margin are used as measures of corporate performance. The ratio of debt to total assets, the ratio of total annual dividends to equity, the ratio of total annual dividends plus stock buybacks to equity, the ratio of capital expenditure to physical fixed assets, R\&D intensity, the ratio of acquisitions to total assets, and the cash and equivalents ratio are used as measures of corporate behavior. $X_{i, t}$ denotes control variables that measure various corporate attributes such as firm size. $Y_{t}$ is a year dummy. $I N S T_{i, t}$ denotes the institutional investor ownership ratio or the foreign institutional investor ownership ratio at the beginning of each year. JSC is a dummy variable that takes a value of 1 for 2014, when the JSC was implemented, and subsequent years. INST*JSC is an interaction term between the institutional investor ownership ratio and the $J S C$ dummy. The main focus of this analysis is on this interaction term. If the JSC changed institutional investors' attitudes, a higher institutional investor ownership ratio (especially, the foreign institutional investor ownership ratio) would lead to a greater change in corporate behavior or performance. The interaction term is considered to capture such a phenomenon.

The analysis also focuses on the JSC dummy used to examine the overall effect of the series of reforms that ensued from the 2014 introduction of the JSC. It is assumed here that the JSC dummy captures reform-related factors, whereas the year dummy in the model captures other factors common to firms, including macroeconomic factors. The analysis considers TSE-1 firms and the period from 2010 to 2018. A fixed-effects model is used for the estimation to control for firm-specific effects. It must be noted that causal relationships are not fully considered in the following analysis, and that some results may reflect reverse causality. ${ }^{17}$

Table 9 summarizes the estimation results. Panel 1 shows the results for the models with the all institutional investor ownership ratio as the explanatory variable; Panel 2 shows the

\footnotetext{
17 The estimation method used here does not completely eliminate the effects of investors' preference for high-performing firms, firms that actively make high-risk investments, and firms with high shareholder returns. Future studies are needed to resolve this issue through more detailed analysis.
} 
results for the models with the foreign institutional investor ownership ratio as the explanatory variable.

--Table 9 about here--

For 2010 and subsequent years, the institutional investor ownership ratio has a significant positive association with ROA and operating profit margin. These results are consistent with the results of previous studies, including those by Aggarwal et al. (2011) and Ferreira and Matos (2008) who examined the relationship between the institutional investor ownership ratio and corporate performance in 27 countries. However, the coefficient of the interaction term is not statistically significant: the result does not show that the positive association between institutional investor ownership ratio and ROE was enhanced by the implementation of the JSC. The relationship between the institutional investor ownership ratio and ROE is positive but not statistically significant. The same result is observed for the models in which the foreign institutional investor ownership ratio is used in place of the institutional investor ownership ratio. Therefore, the analysis does not find evidence that firms with a higher institutional investor ownership ratio gained extra profitability due to the implementation of the JSC.

Given that the institutional investor ownership ratio rose over the period being considered, we can calculate that the average increase in the institutional investor ownership ratio (8 percentage points) and a one standard deviation increase in the ratio (16.5 percentage points) correspond to an increase in ROA by 0.13 and 0.39 percentage points, respectively. In other words, the increase in the institutional investor ownership ratio during the Abenomics period corresponds to about 10 percent of the 1.1 percentage point increase in ROA that occurred during the same period. Applying the same calculation to profit margin, we can see that the average increase in the institutional investor ownership ratio ( 8 percentage points) and a one standard deviation increase in the ratio correspond to an increase in profit margin by 0.19 and 0.59 percentage points, respectively. That is, the increase in the institutional investor ownership ratio during the 2012-2017 period corresponds to more than 30 percent of the 1.75 percentage point increase in profit margin for the same period.

Currently, the effects of the corporate governance reforms on investment are not 
necessarily clear. There is a positive and significant association between capital expenditure and the institutional investor ownership ratio. The coefficient of the interaction term, however, is negative and significant. The results are similar for the foreign institutional investor ownership ratio (Panel 2). Taken together, these results imply that while capital expenditure tends to increase as the institutional investor ownership ratio increases, this tendency weakened after the implementation of the JSC. ${ }^{18}$ In addition, the institutional investor ownership ratio is not positively associated with $M \& A$ expenditure and $R \& D$ expenditure throughout the period considered in this analysis, even during the reform period. The above estimation results do not provide evidence that capital investment, $M \& A$ expenditure, and $R \& D$ expenditure clearly increased due to reforms, despite what was anticipated under Abenomics.

While the relationship between the institutional investor ownership ratio and investment is not clear, the relationship between the institutional investor ownership ratio and payout is strong. The institutional investor ownership ratio is significantly positively associated with the ratio of total annual dividends to equity and with the ratio of total annual dividends plus stock buybacks to equity. Previous studies have found a similar tendency in the United States. ${ }^{19}$ The coefficient of the interaction term between the institutional investor ownership ratio and the $J S C$ dummy is positive. In particular, it is statistically significant at the 1 percent level in the model whose dependent variable is the ratio of total annual dividends plus stock buybacks to equity. The coefficient of the interaction term is 0.013 whereas the coefficient of the institutional investor ownership ratio is 0.020 , which suggests that the effect of the implementation of the JSC on profit allocation was quite substantial. A similar result is obtained for the models in which the overseas institutional investor ownership ratio is used in place of the institutional investor ownership ratio. It is therefore likely that, after implementation of the Code, the tendency for shareholder returns to increase with an increasing institutional investor ownership ratio became stronger.

\footnotetext{
${ }^{18}$ According to the study by Ferreira and Matos (2008), which analyzed the relationship between the institutional investor ownership ratio and capital investment, a firm with a higher institutional investor ownership ratio tends to have a lower level of capital investment.

19 There is, however, debate about the direction of causality. Grinstein and Michaely (2005) argue that institutional investors prefer dividend-paying firms and firms making large stock buybacks, and that the existence of institutional investors does not lead to higher payouts by firms. In contrast, Crane et al. (2016) focused on stock index composition in their analysis and showed that institutional investor ownership is positively associated with dividend payouts.
} 
The relationships of the institutional investor ownership ratio with financial leverage and with the ratio of interest-bearing debt to total assets are both negative and significant. Contrary to what would normally be assumed, this result implies that firms with a high institutional investor ownership ratio were less dependent on debt; that is, they used their increased profit to reduce debt. For the model focusing on financial leverage, the coefficient of the interaction term is positive and significant, albeit at the 10 percent level, which implies that after the implementation of the JSC, increased institutional investor ownership reduced this tendency regarding debt. However, the estimated positive coefficient is small, and the overall effect of institutional investor ownership is still negative $(-1.74=-1.979+0.24)$. The coefficient of the $J S C$ dummy is also negative and significant, which suggests that the corporate governance reforms did not mitigate the tendency for debt reduction.

The coefficient for the relationship between the cash to assets ratio and the institutional investor ownership ratio is positive and significant, which shows that firms with a higher institutional investor ownership ratio are likely to have a higher cash ratio. The coefficient of the interaction term between the institutional investor ownership ratio and the $J S C$ dummy and the coefficient of the interaction term between the foreign institutional investor ownership ratio and the JSC dummy are not statistically significant. The result implies that the corporate governance reforms were not strong enough to change the tendency of Japanese firms to hold on to their profits. Jidinger and Miyajima (2019) analyzed how firms use funds obtained through the sale of relational shareholdings and find evidence for increased holding of cash along with increased dividend payouts and increased stock buybacks, but no evidence of increased real investments. Their results are consistent with ours.

The results presented above can be summarized as follows. Corporate governance reforms under Abenomics may have contributed to increased profits due to an increase in profit margins. The increased profits were not necessarily directed to investment, and some of the increased profits were used for payout and debt reduction with firms holding the rest as cash.

\section{Consequences of Abenomics: A Tentative Conclusion}

The year 2015 is often referred to as the first year of corporate governance in Japan. Yet 
corporate governance reforms under Abenomics did not bring discontinous changes to corporate governance systems. Japanese corporate governance systems had already been evolving since the 1997 banking crisis. Japanese firms were once commonly characterized by the main bank system, cross-shareholding, and boards consisting of internally appointed directors. However, their reorganization efforts after the banking crisis separated hybrid firms, whose external governance systems had significantly shifted to market-based systems and had been combined with traditional relationship-based internal governance mechanisms, from traditional Japanese firms that continued to lag behind in terms of external and internal governance (Jackson and Miyajima, 2007). What kinds of changes, then, did the reforms bring to Japanese corporate governance systems?

The series of reform measures implemented were significant because they encouraged institutional investors to exercise their voting rights and engage in corporate governance, strongly promoted board reforms, promoted effective capital use and reduction of cross-shareholdings by inducing firms to reexamine their "bedrock" relational shareholdings, and increased the attractiveness of the Japanese market, which led to increased investments from overseas.

Comparison of the changes resulting from corporate governance reforms under Abenomics with results from the first peak of reforms following the banking crisis can be summarized as follows. Whereas earlier reforms introduced a hybrid structure into Japanese corporate governance systems and made these systems more diverse, the subsequent corporate governance reforms led to a further transition corporate governance structure into hybrid structure and promoted fine-tuning of hybrid governance systems. The reforms advanced the structural transition of governance systems at traditional Japanese firms that lagged behind in implementing reforms by promoting an increase in the institutional investor ownership ratio, reorganization of the board of directors, and elimination of relational shareholding (insider ownership). The reforms also induced firms whose governance systems had already had hybrid structure to fine-tune their systems through stock buybacks conducted in response to an increase in institutional investors, through adjustment of ownership structure (e.g., introduction of multiple-class shares), through an increase in independent outside directors, and through creation of optional committees. 


\section{Impacts on Corporate Behavior}

What effects did corporate governance reforms have on corporate behavior? Since the reforms are still in progress, we should wait a while before reaching a final conclusion. However, 4 to 5 years have already passed since the introduction of the JSC in 2014 and the CGC in 2015. We can therefore come to a tentative conclusion.

Our analysis finds no evidence of the corporate governance reforms leading to increased corporate performance through institutional investors' increased influence or appointment of independent directors. However, if the reforms led to an increase in the institutional investor ownership ratio through improvement of the attractiveness of the Japanese market, then the reforms can be considered to have contributed, to some extent, to the increased corporate performance observed in 2013 and subsequent years through enhanced discipline in corporate management. At the same time, the reforms did not clearly succeed in directing increased profits during the Abenomics period to real economic activity. Our analysis shows that the positive relationship between institutional investor ownership and real investment weakened during the reform period and finds no clear evidence of institutional investor ownership influencing M\&A and R\&D expenditures. Our estimation results imply that the corporate governance reforms did not have an impact that was strong enough to change corporate managers' attitudes toward risk and investment.

The effects of corporate governance reforms on profit allocation can be clearly seen. After the reforms, the responsiveness of stock buybacks to the institutional investor ownership ratio increased by more than 60 percent and would further increase with consideration given to the institutional investor ownership ratio itself. The direct result of the reforms was increased allocation of profits to shareholders. Increased profits gained during the Abenomics period were also directed to debt reduction, and the corporate governance reforms did not sufficiently curb the phenomenon. The increased shareholder returns and debt reduction did not deplete firms' profits, which resulted in accumulation of cash and equivalents.

In sum, the reforms under Abenomics were a powerful driving force behind making governance systems more shareholder-centric but have not succeeded in changing corporate managers' attitudes toward risk in order to increase investments. Therefore, if a trickle-down 
effect was expected as a way to equally distribute the benefits of the reforms to the public, this has not been sufficiently realized yet.

It is too early to say that Abenomics has failed, or that pressure from myopic shareholders has intensified, based solely on the findings that corporate behavior has not sufficiently changed and shareholder returns have increased. It takes time for any reforms to change corporate behavior. Also, there has been no evidence of stock buybacks being used for increased compensation, as discussed by Almeida et al. (2016) in the context of the U.S. market, and increased shareholder returns have not substantially reduced real investment. It is true, however, that the vision of Abenomics has not been realized as anticipated. ${ }^{20}$ In order for the Japanese economy to grow in the future, we need to prudently examine what should be expected of corporate governance reforms and how the reforms should be complemented by other policies. $^{21}$

\footnotetext{
${ }^{20}$ If one divides the sample into two samples based on corporate growth potential and estimates the models shown in Table 9 with the new samples, the positive effects of institutional investor ownership on the responsiveness of dividend payouts is larger for firms with low growth potential. ${ }^{21}$ Also, our estimation results may imply that it is time we need to consider how to prevent abuse of shareholder rights that sacrifices long-term investment (e.g., R\&D and human capital investment).
} 


\section{References}

Aggarwal, R., I. Erel, M. Ferreira, and P. Matos, 2011. Does governance travel around the world? Evidence from institutional investors, Journal of Financial Economics 100, 154-181.

Aoki, M., G., Jackson, and H., Miyajima, 2007. Corporate Governance in Japan: Institutional Change and Organizational Diversity, Oxford, Oxford University Press.

Almeida, H., Fos, V., \& Kronlund, M. (2016). The real effects of share repurchases. Journal of Financial Economics, 119(1), 168-185.Crane, A., S. Michenaud, and J. Weston, 2016. The effect of institutional ownership on payout policy: Evidence from index thresholds, Review of Financial Studies 29, 1377-1408.

Becht, M., J. Franks, J. Grant, and H. Wagner, 2017. The returns to hedge fund activism: An international study, Review of Financial Studies 30:2933-2971.

Becht, M., Franks, J., H. Miyajima and K. Suzuki (2019), The role of quiet activism, ongoing project

Buchanan, J., D. Chai and S. Deakin, 2012. Hedge Fund Activism in Japan: The Limits of Shareholder Primacy, Cambridge: Cambridge University Press.

Duchin, R., J. Matsusaka, and O. Ozbas, 2010. When are outside directors effective?, Journal of Financial Economics 96, 195-214.

Edmans, A., 2011. Does the stock market fully value intangibles? Employee satisfaction and equity prices, Journal of Financial Economics 101, 621-640.

Edmans, A., V. W. Fang, and A. H. Huang, 2018. The long-term consequences of short-term incentives, ECGI Finance Working Paper No. 527.

Fauver, L., M. Hung, X., X. Li, and A. Taboada, 2017. Board reforms and firm value: Worldwide evidence, Journal of Financial Economics 125, 120-142.

Ferreira, M., and P. Matos, 2008. The colors of investors' money: The role of institutional investors around the world, Journal of Financial Economics 88, 499-533.

Franks, J., C. Mayer, and H. Miyajima, 2014. The ownership of Japanese corporations in the 20th century, Review of Financial Studies 27, 2580-2625.

Franks, J., C. Mayer, H. Miyajima, and Ryo Ogawa, (2018), Share Repurchases and the control of firms: Evidence from Japan, RIETI.

Gombers, P., and A., Metrick, 2001, Institutional investors and equity prices, Quarterly Journal of Economics 116, 229-259.

Grinstein, Y., and R. Michaely, 2005. Institutional holdings and payout policy, Journal of Finance 60, 1389-1426.

Hamao, Y. and Matos, P. (2018) "U.S.-Style Investor Activism in Japan: The First Ten Years," Journal of the Japanese and International Economies, Vol. 48, 29-54 
Huberman, G., 2001. Familiarity breeds investment, Review of Financial Studies 14, 659-680.

Ikeda, N., K. Inoue, and S. Watanabe, 2018. Enjoying the quiet life: Corporate decision-making by entrenched managers, Journal of The Japanese and International Economies 47, 55-69.

Jackson, G. and H. Miyajima, 2007. Introduction: The diversity and change of corporate governance in Japan, in M. Aoki, G. Jackson, and H. Miyajima (eds.), Corporate governance in Japan: Institutional change and organizational diversity, Oxford: Oxford University Press, pp. 1-47.

Jidinger J., and H. Miyajima, 2019. Does regulation matter?: Effects of the corporate governance reforms on the relational shareholdings in Japan, Working paper.

Kay, J., 2012. "The Kay Review of UK Equity Market and Long-term Decision", Investor Management Association.

Miyajima, H. and F. Kuroki, 2007. The unwinding of cross-shareholding in Japan: Causes, effects, and implications, in M. Aoki, G. Jackson, and H. Miyajima (eds.), Corporate governance in Japan: Institutional change and organizational diversity, Oxford: Oxford University Press, pp. 79-124.

Miyajima, H. and R. Ogawa, 2016. Convergence or emerging diversity? Understanding the impact of foreign investors on corporate governance in Japan, RIETI Discussion Paper Series $16-\mathrm{E}-053$.

Miyajima, H., R. Ogawa, and T. Saito, 2018. Changes in corporate governance and top executive turnover: The evidence from Japan, Journal of The Japanese and International Economies 47, $17-31$.

OECD, 2012. "Corporate Governance, Value Creation and Growth: The Bridge Between Finance and Enterprise", OECD Publishing.

Porter, M. E. (1992). Capital disadvantage: America's failing capital investment system, Harvard Business Review, 70(5), 65-82.

Porter, M. E. (1994), Capital Choices (Harvard University Press).

Shleifer, A., and Vishny, R., 1990. Equilibrium short horizons of investors and firms, American Economic Review 80, 148-153.

Stein, J., 1988. Takeover threats and managerial myopia, Journal of Political Economy 96, 61-80.

Tanaka, W., 2017. Current state and outlook of corporate governance reform-With a focus on the board of directors system, Working paper at Waseda University: WCG WP \#2017-002. 
Table 1: Major events related to corporate governance reforms under Abenomics

Dec. 2012 Formation of the Second Abe Cabinet

Establishment of the Headquarters for Japan's Economic Revitalization

Feb. 2013 ISS recommended voting against the appointment of a top executive "if the board after the shareholder meeting does not include at least one outsider, regardless of independence."

Jun.2013 The Japan Revitalization Strategy put forth the principles to be followed by institutional investors in fulfilling their fiduciary duty (e.g., encouraging firms through dialogue to pursue medium- to long-term growth).

Jun. 2013 Toyota's general shareholder meeting; three outside directors selected. Kyocera, Sumitomo Corporation, and FANUC followed suit.

Jan. 2014 Start of the JPX400 index

Canon announced the appointment of outside directors.

Feb. 2014 Creation of the JSC

Jun. 2014 Revision of Japan Revitalization Strategy. It put forth enhanced corporate governance as part of the Emergency Structural Reform Program.

Aug. 2014 Ito Report, "Competitiveness and Incentives for Sustainable Growth: Building Favorable Relationships between Companies and Investors"

Dai-ichi Life decided to disclose voting results.

Oct. 2014 Revision of ISS proxy voting policies (ROE criterion, board composition, creation of an audit committee).

Mar. 2015 The Financial Services Agency and the Tokyo Stock Exchange announced the first draft of corporate governance guidelines.

May 2015 Amendment of the Companies Act (audit and supervisory committee; explanation for not establishing the committee; stricter requirements for outside directors)

Jun. 2015 Mizuho Bank announced further dissolution of cross-shareholding.

2015 Revision of the Japan Revitalization Strategy

Implementation of the CGC

Jun. 2016 Japan Revitalization Strategy 2016; shift of reforms from formality to substance

Dec. 2016 The JSC adopted by 214 financial institutions.

Mar. 2017 CGS Study Group's first-term report

May 2017 Revised JSC (disclosure of detailed voting results)

Jun. 2017 The GPIF published its voting principles and requested institutions entrusted with asset management to disclose detailed voting results.

Future Investment Strategy 2017 (Cabinet decision)

Aug. 2017 Corporate governance reports; description on the treatment of retired representative directors

Dec. 2017 CGS Study Group, second term; follow-up conference; group governance

Mar. 2018 Revision of the CGC

Jun. 2018 Future Investment Strategy 2018; operational guidelines for group governance

Nov. 2018 Creation of the Study Group on Fair M\&A

Jun. 2019 Operational guidelines on group governance

1) ISS 2013 Japan Proxy Voting Summary Guidelines

(https://www.issgovernance.com/file/2013-policies/2013ISSJapanGuidelinesSummaryRev01312013.pdf) 
Table 2: Guidelines for voting (selected financial institutions)

\begin{tabular}{|c|c|c|}
\hline \multicolumn{3}{|r|}{ of Criteria for voting against appointment of a director } \\
\hline & institution & \\
\hline Proxy advisory firm & ISS & $\begin{array}{l}\text { Average ROE for the past } 5 \text { years below } 5 \% \text { and no prospect of } \\
\text { improvement }\end{array}$ \\
\hline \multirow[t]{3}{*}{ Trust banks } & $\begin{array}{l}\text { Sumitomo Mitsui } \\
\text { Trust Bank }\end{array}$ & $\begin{array}{l}\text { ROE in the bottom quartile among TOPIX firms in three consecutive } \\
\text { periods }\end{array}$ \\
\hline & $\begin{array}{l}\text { Mitsubishi UFJ } \\
\text { Trust and Banking }\end{array}$ & ROE below $5 \%$ in five consecutive periods and no prospect of improvement \\
\hline & $\begin{array}{l}\text { Asset Management } \\
\text { One }\end{array}$ & $\begin{array}{l}\text { ROE below in the lowest tertile among TSE-1 firms in three consecutive } \\
\text { periods }\end{array}$ \\
\hline \multirow{6}{*}{$\begin{array}{l}\text { Investment trust } \\
\text { asset management } \\
\text { firms }\end{array}$} & $\begin{array}{l}\text { Sumitomo Mitsui } \\
\text { Asset Management }\end{array}$ & $\begin{array}{l}\text { ROE below the listed firm mean, the median, or } 5 \% \text { in the most recent three } \\
\text { periods }\end{array}$ \\
\hline & & \\
\hline & $\begin{array}{l}\text { Sumitomo Mitsui } \\
\text { Trust Asset } \\
\text { Management }\end{array}$ & ROE below $5 \%$ in the past three consecutive periods \\
\hline & $\begin{array}{l}\text { Nomura Asset } \\
\text { Management }\end{array}$ & $\begin{array}{l}\text { ROE below } 5 \% \text { and below the industry median in the most recent three } \\
\text { consecutive periods; no management efforts for improvement observed (see } \\
\text { note) }\end{array}$ \\
\hline & $\begin{array}{c}\text { Tokio Marine Asset } \\
\text { Management }\end{array}$ & ROE below $5 \%$ in the past three consecutive periods \\
\hline & $\begin{array}{l}\text { Resona Asset } \\
\text { Management }\end{array}$ & $\begin{array}{l}\text { Vote against a representative director serving } 3 \text { years or more at an } \\
\text { inefficiently managed firm (ROE below } 5 \% \text { in three consecutive periods) } \\
\text { with ROE in the bottom } 25 \% \text { in the industry in } 3 \text { consecutive years ( } 10 \% \text { in } \\
\text { recent periods), if no rational, convincing explanation is provided. }\end{array}$ \\
\hline \multirow[t]{2}{*}{$\begin{array}{l}\text { Life insurance } \\
\text { company }\end{array}$} & Dai-ichi Life & $\begin{array}{l}\text { Operating loss (consolidated) in the most recent three consecutive periods; } \\
\text { ordinary loss (consolidated) in the most recent three consecutive periods; } \\
\text { net loss (consolidated) in the most recent three consecutive periods }\end{array}$ \\
\hline & & Allocation of surplus \\
\hline \multirow[t]{2}{*}{ Trust bank } & \multirow[t]{2}{*}{$\begin{array}{l}\text { Mitsubishi UFJ } \\
\text { Trust and } \\
\text { Banking }\end{array}$} & $\begin{array}{l}\text { Vote against, in principle, if average ROE for the past } 3 \text { years and most } \\
\text { recent ROE are below } 5 \% \text {, if the need for internal reserves is low, and if the } \\
\text { total return ratio is below } 30 \% \text {. }\end{array}$ \\
\hline & & $\begin{array}{l}\text { Vote against, in principle, if (cash and equivalents }+ \text { long- and short-term } \\
\text { securities) / total assets is } 50 \% \text { or higher, if average ROE for the past three } \\
\text { years and the most recent ROE are below } 8 \% \text {, and if requested explanations } \\
\text { from the firm on its capital policy are deemed insufficient. }\end{array}$ \\
\hline
\end{tabular}


Table 3: Institutional ownership of TSE-1 firms

Pane 11: Institutional ow nersh ip

\begin{tabular}{|c|c|c|c|c|c|}
\hline & 2010 & 2012 & 2014 & 2017 & $\begin{array}{l}\text { Change from } \\
2012 \text { to } 2017\end{array}$ \\
\hline M ean & $19.5 \%$ & $19.8 \%$ & $23.3 \%$ & $27.8 \%$ & $8.0 \%$ \\
\hline M ed ian & $16.0 \%$ & $16.4 \%$ & $20.4 \%$ & $25.6 \%$ & $9.3 \%$ \\
\hline Standard deviation & $15.4 \%$ & $15.6 \%$ & $16.2 \%$ & $16.5 \%$ & \\
\hline Coeffic ien t of variation & 0.790 & 0.788 & 0.694 & 0.592 & \\
\hline \multicolumn{6}{|c|}{$Q u$ intiles ofm arket va lue of equ ity at the end of each year } \\
\hline \multicolumn{6}{|l|}{ F irstqu intile } \\
\hline M ean & $6.0 \%$ & $6.5 \%$ & $8.9 \%$ & $13.1 \%$ & $6.6 \%$ \\
\hline M ed ian & $2.7 \%$ & $4.9 \%$ & $7.4 \%$ & $11.3 \%$ & $6.4 \%$ \\
\hline Standard deviation & $6.4 \%$ & $6.6 \%$ & $7.6 \%$ & $8.5 \%$ & \\
\hline \multicolumn{6}{|l|}{ Second qu intile } \\
\hline M ean & $12.1 \%$ & $11.7 \%$ & $15.1 \%$ & $20.4 \%$ & $8.6 \%$ \\
\hline M ed ian & $9.9 \%$ & $9.5 \%$ & $14.0 \%$ & $18.6 \%$ & $9.2 \%$ \\
\hline Standard deviation & $9.8 \%$ & $9.1 \%$ & $10.3 \%$ & $11.7 \%$ & \\
\hline \multicolumn{6}{|l|}{ Th ird qu in tile } \\
\hline M ean & $17.4 \%$ & $18.2 \%$ & $22.3 \%$ & $27.9 \%$ & $9.7 \%$ \\
\hline$M$ ed ian & $15.6 \%$ & $17.1 \%$ & $21.2 \%$ & $26.6 \%$ & $9.5 \%$ \\
\hline Standard deviation & $10.3 \%$ & $11.0 \%$ & $12.1 \%$ & $13.0 \%$ & \\
\hline \multicolumn{6}{|l|}{ Fourth qu in tile } \\
\hline M ean & $26.5 \%$ & $26.9 \%$ & $30.0 \%$ & $34.0 \%$ & $7.1 \%$ \\
\hline$M$ ed ian & $25.3 \%$ & $26.7 \%$ & $29.7 \%$ & $33.6 \%$ & $6.9 \%$ \\
\hline Standard deviation & $12.5 \%$ & $13.3 \%$ & $13.1 \%$ & $14.5 \%$ & \\
\hline \multicolumn{6}{|l|}{$F$ ifth qu in tile } \\
\hline M ean & $36.9 \%$ & $37.2 \%$ & $40.7 \%$ & $44.6 \%$ & $7.4 \%$ \\
\hline M ed ian & $36.2 \%$ & $37.8 \%$ & $41.1 \%$ & $45.6 \%$ & $7.8 \%$ \\
\hline Standard deviation & $13.8 \%$ & $13.8 \%$ & $13.4 \%$ & $13.5 \%$ & \\
\hline
\end{tabular}


Panel2 : Fore ign in stitutional ow nersh ip

\begin{tabular}{|c|c|c|c|c|c|}
\hline & 2010 & 2012 & 2014 & 2017 & $\begin{array}{l}\text { Change from } \\
2012 \text { to } 2017\end{array}$ \\
\hline M ean & $11.4 \%$ & $12.2 \%$ & $15.2 \%$ & $16.8 \%$ & $4.7 \%$ \\
\hline M ed ian & $7.8 \%$ & $8.8 \%$ & $12.5 \%$ & $15.0 \%$ & $6.2 \%$ \\
\hline Standard deviation & $10.9 \%$ & $11.2 \%$ & $12.1 \%$ & $12.0 \%$ & \\
\hline Coeffic ien t of variation & 0.959 & 0.926 & 0.799 & 0.712 & \\
\hline \multicolumn{6}{|c|}{ Qu intiles ofm arket value of equ ity at the end of each year } \\
\hline \multicolumn{6}{|l|}{ F irstqu in tile } \\
\hline M ean & $2.7 \%$ & $3.2 \%$ & $4.5 \%$ & $6.1 \%$ & $2.9 \%$ \\
\hline$M$ ed ian & $1.4 \%$ & $1.7 \%$ & $3.1 \%$ & $4.5 \%$ & $2.9 \%$ \\
\hline Standard deviation & $4.1 \%$ & $4.7 \%$ & $4.8 \%$ & $5.4 \%$ & \\
\hline \multicolumn{6}{|l|}{ Second qu in tile } \\
\hline M ean & $5.9 \%$ & $6.0 \%$ & $8.5 \%$ & $11.0 \%$ & $5.0 \%$ \\
\hline M ed ian & $3.7 \%$ & $4.2 \%$ & $6.6 \%$ & $9.7 \%$ & $5.5 \%$ \\
\hline Standard deviation & $6.6 \%$ & $6.0 \%$ & $6.9 \%$ & $8.0 \%$ & \\
\hline \multicolumn{6}{|l|}{ Th ird qu in tile } \\
\hline M ean & $9.2 \%$ & $10.5 \%$ & $14.2 \%$ & $17.1 \%$ & $6.5 \%$ \\
\hline$M$ ed ian & $7.3 \%$ & $8.7 \%$ & $12.7 \%$ & $15.9 \%$ & $7.2 \%$ \\
\hline Standard deviation & $7.1 \%$ & $7.8 \%$ & $9.1 \%$ & $9.7 \%$ & \\
\hline \multicolumn{6}{|l|}{ Fourth qu in tile } \\
\hline M ean & $15.2 \%$ & $15.9 \%$ & $19.6 \%$ & $21.2 \%$ & $5.3 \%$ \\
\hline M ed ian & $13.8 \%$ & $14.5 \%$ & $19.1 \%$ & $21.0 \%$ & $6.5 \%$ \\
\hline Standard deviation & $8.8 \%$ & $9.5 \%$ & $9.8 \%$ & $10.1 \%$ & \\
\hline \multicolumn{6}{|l|}{$F$ ifth qu in tile } \\
\hline M ean & $24.0 \%$ & $25.2 \%$ & $28.9 \%$ & $29.2 \%$ & $4.0 \%$ \\
\hline M ed ian & $23.5 \%$ & $24.3 \%$ & $29.1 \%$ & $28.4 \%$ & $4.1 \%$ \\
\hline Standard deviation & $10.8 \%$ & $11.1 \%$ & $10.5 \%$ & $10.5 \%$ & \\
\hline
\end{tabular}


Table 4: Characteristics of board of directors

\begin{tabular}{|c|c|c|c|c|c|c|}
\hline & \multicolumn{2}{|c|}{ TSE 1 firm $S$} & \multicolumn{2}{|c|}{ PX400 firm s } & \multicolumn{2}{|c|}{ N on-JP400 firm s } \\
\hline & 2013 & 2018 & 2013 & 2018 & 2013 & 2018 \\
\hline M ean num ber of d irectors & 8.6 & 9.2 & 10.4 & 10.6 & 8.1 & 8.8 \\
\hline M ean num ber of outs ide directors & 1.2 & 2.7 & 1.8 & 3.3 & 1.0 & 2.5 \\
\hline N um ber of outs ide directors $=0(\%)$ & $37.6 \%$ & $0.3 \%$ & $24.3 \%$ & $0.0 \%$ & $41.3 \%$ & $0.4 \%$ \\
\hline Num ber $=1(\%)$ & $31.7 \%$ & $5.1 \%$ & $26.1 \%$ & $1.3 \%$ & $33.2 \%$ & $6.0 \%$ \\
\hline Num ber $=3(\%)$ & $13.7 \%$ & $45.2 \%$ & $27.2 \%$ & $67.7 \%$ & $9.9 \%$ & $39.9 \%$ \\
\hline Num ber $=3$ or $m$ ore $(\%)$ & $12.3 \%$ & $41.8 \%$ & $17.8 \%$ & $46.4 \%$ & $10.8 \%$ & $40.7 \%$ \\
\hline Com pany w ith nom inating com m ittee (\%) & $2.5 \%$ & $2.9 \%$ & $6.0 \%$ & $8.8 \%$ & $1.5 \%$ & $1.5 \%$ \\
\hline Com pany w ith aud it and supervisory com $m$ ittee (\%) & - & $24.4 \%$ & - & $15.0 \%$ & - & $26.6 \%$ \\
\hline Com pany w ith voluntary nom inating com $m$ ittee (\%) & $5.9 \%$ & $31.4 \%$ & $14.6 \%$ & $52.4 \%$ & $3.5 \%$ & $26.5 \%$ \\
\hline Com pany w ith voluntary com pensation com $m$ ittee (\%) & $8.6 \%$ & $34.9 \%$ & $19.1 \%$ & $54.9 \%$ & $5.7 \%$ & $30.2 \%$ \\
\hline
\end{tabular}

D ata source : Tokyo Stock Exchange, Yaku in Sh ik iho (D irectory of d irectors) pub lished byToyo Ke iza i Sh inposha 
Table 5: The effect of outside directors on corporate performance

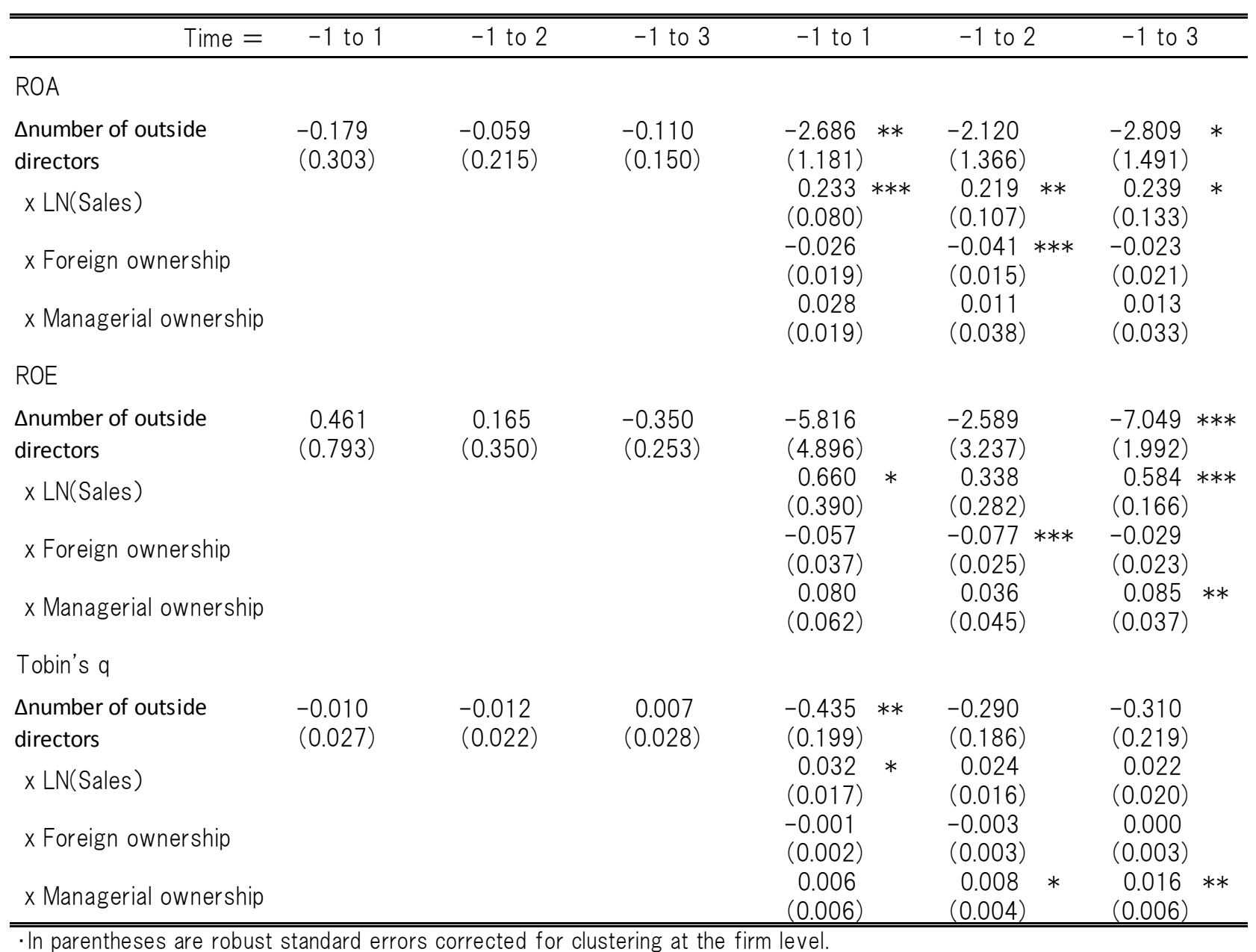

$* * * \mathrm{p}<0.01, * * \mathrm{p}<0.05, * \mathrm{p}<0.1$ 
Note: These data contain average data on all companies listed on the Tokyo Stock Exchange and was constructed using information from Nikkei Cges. Given the lack of data on relational shareholding, we used FY2016 as a conditional base year, which means that for the period 2005 until 2014 , each company that falls within the top 25\% (above the 75th percentile) is recognized as 1 and that each company in the bottom $25 \%$ (below the 25 th percentile) is recognized as 0 . Using these constraints, we then measure the difference between the top 25\% and bottom $25 \%$ companies for each year before the CG reform in 2015. The thresholds for relational shareholding asset size to total assets is $0.87 \%$ for the bottom $25 \%$ and $6.38 \%$ for the top 25 . The cross-shareholding ratio, however, is $0.1 \%$ for the bottom $25 \%$ and more than or equal to $14.2 \%$ for the top $25 \%$.

\begin{tabular}{|c|c|c|c|c|c|c|c|}
\hline & \multirow[t]{2}{*}{$T S E$} & \multicolumn{2}{|c|}{ Relational shareholding } & \multirow{2}{*}{$\frac{\text { T-test of means }}{\text { (Top - Bottom) }}$} & \multicolumn{2}{|c|}{ Cross shareholding } & \multirow{2}{*}{ T-test of means } \\
\hline & & Top 25 & Bottom 25 & & Top 25 & Bottom 25 & \\
\hline ROA & $5,89 \%$ & $5,22 \%$ & $7,19 \%$ & $-1,96 \% * * *$ & $4,62 \%$ & $8,68 \%$ & $-4,05 \%$ *** \\
\hline Cash Flow & $6,20 \%$ & $5,69 \%$ & $7,40 \%$ & $-1,71 \%$ *** & $5,36 \%$ & $8,15 \%$ & $-2,78 \% * * *$ \\
\hline Tobin's Q & 1,16 & 1,05 & 1,30 & $-0,25 \% * * *$ & 1,00 & 1,48 & $-0,48 * * *$ \\
\hline Domestic Institutional Shareholder & $22.89 \%$ & $22,67 \%$ & $24,47 \%$ & $-1,8 \% * * *$ & $19,89 \%$ & $22,40 \%$ & $-2,51 \% * * *$ \\
\hline Foreign Institutional Shareholder & $13,72 \%$ & $12,82 \%$ & 15,80 & $-2,97 \%$ *** & $10,89 \%$ & $15,13 \%$ & $-4,24 \% * * *$ \\
\hline Leverage & $52,71 \%$ & $48,31 \%$ & 55,09 & $-6,77 \% * * *$ & $52,82 \%$ & $50,29 \%$ & $2,53 \% * * *$ \\
\hline Total Assets (JPY Billion) & 934,956 & 500,000 & 460,000 & 40,000 & 350,000 & 910,000 & $-560,000 * * *$ \\
\hline Market Cap. (JPY Billion) & 222,723 & 160,000 & 230,000 & $-70,000 * * *$ & 150,000 & 210,000 & $-60,000 * * *$ \\
\hline R\&D to Total Sales & $1.85 \%$ & $2,60 \%$ & $2,97 \%$ & $-0,37 \%$ *** & $2,14 \%$ & $2,57 \%$ & $-0,43 \% * * *$ \\
\hline Capex to Fixed Assets & $14.19 \%$ & $13,05 \%$ & $16,73 \%$ & $-3,68 \%$ *** & $13,65 \%$ & $18,16 \%$ & $-4,51 \% * * *$ \\
\hline
\end{tabular}




\section{Table 7: The yearly decision on Relationship Shareholding}

The first row A addresses the aggregate dataset for all 200 randomly selected companies. The second row B assesses the data provided from each company on each specific relationship shareholding and is the total number of assets held for all 200 companies. In the third panel, we address the average total number of decisions taken to sell the Relationship Shareholding assets for all 200 companies as well as the total number of shareholdings. The decision to sell is determined when a company chooses to decrease or liquidate an acquired Relationship Shareholding asset. The total number of decisions taken to sell a Relationship Shareholding asset is the aggregate of the previously explained term.

\begin{tabular}{|c|c|c|c|c|c|c|c|c|}
\hline & Fiscal Year & 2011 & 2012 & 2013 & 2014 & 2015 & 2016 & 2017 \\
\hline \multirow[t]{3}{*}{ A } & A. Number of Companies in the Dataset & 200 & 200 & 200 & 200 & 200 & 200 & 200 \\
\hline & B. Total Decisions to sell & 57 & 72 & 57 & 80 & 101 & 150 & 178 \\
\hline & (B) / (A) $(\%)$ & $29 \%$ & $36 \%$ & $29 \%$ & $40 \%$ & $51 \%$ & $75 \%$ & $89 \%$ \\
\hline \multirow[t]{3}{*}{ B } & A. Total Number of relationship assets held by 200 companies & 4948 & 5006 & 5083 & 5183 & 5082 & 5125 & 5151 \\
\hline & B. Decisions to sell & 330 & 347 & 326 & 337 & 482 & 737 & 1073 \\
\hline & $(\mathrm{B}) /(\mathrm{A})(\%)$ & $7 \%$ & $7 \%$ & $6 \%$ & $7 \%$ & $9 \%$ & $14 \%$ & $21 \%$ \\
\hline \multirow[t]{2}{*}{$\mathrm{C}$} & Number of Decisions taken to sell assets & 2.74 & 2.89 & 2.84 & 2.69 & 3.35 & 4.31 & 5.79 \\
\hline & Total Number of shares held (Millions) & 26.3 & 25.5 & 26.9 & 26.8 & 27.1 & 24.1 & 21.2 \\
\hline
\end{tabular}


Table 8: Average firm characteristics of TSE1 firms

\begin{tabular}{|c|c|c|c|c|c|c|c|c|c|c|c|c|c|c|c|}
\hline & ROE & ROA & $\begin{array}{c}\text { Net incom e to } \\
\text { sales }\end{array}$ & $\begin{array}{c}\text { perating } \\
\text { incom e to } \\
\text { sales }\end{array}$ & $\begin{array}{l}\text { Sales to } \\
\text { assets }\end{array}$ & $\begin{array}{c}\text { Assets to } \\
\text { equity }\end{array}$ & $\begin{array}{l}\text { Debt to } \\
\text { assets }\end{array}$ & $\begin{array}{l}D \text { ividend to } \\
\text { equ ity }\end{array}$ & $\begin{array}{c}\text { Payout to } \\
\text { equ ity }\end{array}$ & $\begin{array}{l}\text { CAPEX to } \\
\text { fixed assets }\end{array}$ & $\begin{array}{c}\text { Acqu is ition to } \\
\text { assets }\end{array}$ & $R \& D$ to sa les & $\begin{array}{l}\text { Cash to } \\
\text { assets }\end{array}$ & $\begin{array}{l}\text { Institutional } \\
\text { ow nersh ip }\end{array}$ & $\begin{array}{l}\text { Fore ign } \\
\text { institutional } \\
\text { ow nersh ip }\end{array}$ \\
\hline 2000 & 0.012 & 0.060 & 0.015 & 0.058 & 1.014 & 3.753 & 0.266 & 0.013 & 0.017 & 0.136 & 0.001 & 0.025 & 0.188 & $\mathrm{NA}$ & 0.070 \\
\hline 2001 & -0.008 & 0.047 & 0.004 & 0.045 & 1.029 & 3.571 & 0.258 & 0.013 & 0.019 & 0.129 & 0.001 & 0.027 & 0.186 & NA & 0.067 \\
\hline 2002 & 0.018 & 0.055 & 0.013 & 0.053 & 1.066 & 3.473 & 0.246 & 0.013 & 0.021 & 0.119 & 0.001 & 0.027 & 0.191 & NA & 0.065 \\
\hline 2003 & 0.049 & 0.062 & 0.026 & 0.060 & 1.078 & 3.232 & 0.224 & 0.131 & 0.020 & 0.122 & 0.001 & 0.027 & 0.197 & NA & 0.089 \\
\hline 2004 & 0.064 & 0.070 & 0.033 & 0.067 & 1.111 & 3.006 & 0.210 & 0.015 & 0.021 & 0.145 & 0.001 & 0.026 & 0.202 & 0.208 & 0.108 \\
\hline 2005 & 0.062 & 0.071 & 0.035 & 0.068 & 1.115 & 2.814 & 0.192 & 0.016 & 0.022 & 0.161 & 0.001 & 0.025 & 0.187 & 0.233 & 0.131 \\
\hline 2006 & 0.070 & 0.072 & 0.037 & 0.069 & 1.126 & 2.752 & 0.185 & 0.018 & 0.026 & 0.172 & 0.002 & 0.024 & 0.188 & 0.227 & 0.137 \\
\hline 2007 & 0.061 & 0.073 & 0.033 & 0.067 & 1.181 & 2.721 & 0.188 & 0.021 & 0.030 & 0.170 & 0.002 & 0.024 & 0.187 & 0.221 & 0.134 \\
\hline 2008 & -0.016 & 0.052 & 0.004 & 0.044 & 1.195 & 2.883 & 0.215 & 0.024 & 0.036 & 0.157 & 0.002 & 0.027 & 0.199 & 0.217 & 0.112 \\
\hline 2009 & 0.015 & 0.048 & 0.012 & 0.043 & 1.089 & 2.746 & 0.209 & 0.018 & 0.023 & 0.120 & 0.002 & 0.028 & 0.229 & 0.194 & 0.112 \\
\hline 2010 & 0.054 & 0.065 & 0.029 & 0.061 & 1.139 & 2.697 & 0.200 & 0.018 & 0.023 & 0.126 & 0.002 & 0.026 & 0.248 & 0.195 & 0.114 \\
\hline 2011 & 0.050 & 0.063 & 0.028 & 0.059 & 1.131 & 2.622 & 0.193 & 0.019 & 0.024 & 0.140 & 0.003 & 0.027 & 0.254 & 0.196 & 0.114 \\
\hline 2012 & 0.058 & 0.064 & 0.033 & 0.059 & 1.112 & 2.542 & 0.189 & 0.019 & 0.024 & 0.159 & 0.003 & 0.027 & 0.272 & 0.198 & 0.123 \\
\hline 2013 & 0.075 & 0.070 & 0.041 & 0.066 & 1.121 & 2.437 & 0.179 & 0.019 & 0.024 & 0.168 & 0.003 & 0.025 & 0.275 & 0.222 & 0.141 \\
\hline 2014 & 0.073 & 0.071 & 0.044 & 0.068 & 1.098 & 2.337 & 0.175 & 0.019 & 0.026 & 0.169 & 0.003 & 0.025 & 0.280 & 0.233 & 0.152 \\
\hline 2015 & 0.074 & 0.073 & 0.043 & 0.072 & 1.111 & 2.317 & 0.177 & 0.022 & 0.031 & 0.174 & 0.003 & 0.025 & 0.297 & 0.254 & 0.155 \\
\hline 2016 & 0.079 & 0.073 & 0.047 & 0.073 & 1.076 & 2.294 & 0.176 & 0.023 & 0.032 & 0.172 & 0.004 & 0.026 & 0.307 & 0.260 & 0.160 \\
\hline 2017 & 0.086 & 0.075 & 0.051 & 0.077 & 1.073 & 2.256 & 0.170 & 0.024 & 0.031 & 0.172 & 0.004 & 0.025 & 0.311 & 0.278 & 0.168 \\
\hline 2018 & 0.081 & 0.075 & 0.051 & 0.078 & 1.083 & 2.230 & 0.167 & 0.026 & 0.035 & 0.191 & 0.004 & 0.025 & 0.327 & NA & NA \\
\hline
\end{tabular}


Table 9: The effects of institutional ownership on firm performance and behavior

Panel A: Institutional ownership

\begin{tabular}{|c|c|c|c|c|c|c|c|c|c|c|}
\hline & (1) & (2) & (3) & (4) & (5) & (6) & (7) & (8) & (9) & (10) \\
\hline Variab les & ROE & ROA & $\begin{array}{c}0 \text { perating } \\
\text { incom e to } \\
\text { sales }\end{array}$ & $\begin{array}{l}\text { Payout to } \\
\text { equity }\end{array}$ & $\begin{array}{l}\text { D ividend } \\
\text { to equ ity }\end{array}$ & $\begin{array}{l}\text { CAPEX to } \\
\text { fixed } \\
\text { assets }\end{array}$ & $\begin{array}{l}\text { Acqu is itio } \\
n \text { to } \\
\text { assets }\end{array}$ & $\begin{array}{l}R \& D \text { to } \\
\text { sales }\end{array}$ & $\begin{array}{l}\text { D ebt to } \\
\text { assets }\end{array}$ & $\begin{array}{l}\text { Cash to } \\
\text { assets }\end{array}$ \\
\hline \multirow[t]{2}{*}{ Institutional ow nersh ip } & 0.024 & $0.043 * * *$ & $0.039 * * *$ & $0.019 * * *$ & $0.012 * * *$ & $0.092 * * *$ & 0.001 & $0.004 *$ & $-0.116 * * *$ & $0.025 * *$ \\
\hline & $(0.021)$ & $(0.007)$ & $(0.008)$ & $(0.006)$ & $(0.002)$ & $(0.029)$ & $(0.003)$ & $(0.002)$ & $(0.016)$ & $(0.012)$ \\
\hline \multirow[t]{2}{*}{ Institutiona low nersh ip $\times$ JSC dum m y } & 0.001 & -0.004 & 0.000 & $0.015 * * *$ & $0.003 * *$ & $-0.058 * * *$ & 0.001 & -0.000 & 0.001 & $-0.016 *$ \\
\hline & $(0.011)$ & $(0.005)$ & $(0.005)$ & $(0.003)$ & $(0.001)$ & $(0.015)$ & $(0.001)$ & $(0.002)$ & $(0.010)$ & $(0.009)$ \\
\hline \multirow[t]{2}{*}{ JSC dum m y } & -0.007 & $-0.005 * * *$ & -0.007 **** & $-0.002 *$ & $-0.002 * * *$ & $0.033 * * *$ & -0.000 & -0.000 & $-0.042 * * *$ & 0.004 \\
\hline & $(0.005)$ & $(0.002)$ & $(0.002)$ & $(0.001)$ & $(0.000)$ & $(0.006)$ & $(0.000)$ & $(0.001)$ & $(0.003)$ & $(0.003)$ \\
\hline \multirow[t]{2}{*}{ LN (assets) } & $0.045 * * *$ & $0.009 * *$ & $0.028 * * *$ & -0.003 & $0.004 * * *$ & 0.046 *a* & $0.006 * * *$ & $-0.003 *$ & $0.100 * * *$ & $-0.015 * *$ \\
\hline & $(0.010)$ & $(0.004)$ & $(0.004)$ & $(0.002)$ & $(0.001)$ & $(0.013)$ & $(0.001)$ & $(0.002)$ & $(0.008)$ & $(0.006)$ \\
\hline \multirow[t]{2}{*}{ Fore ign sales to totalsales } & -0.020 & $0.012 *$ & -0.002 & -0.003 & $-0.003 *$ & 0.019 & -0.004 & 0.001 & 0.010 & -0.007 \\
\hline & $(0.016)$ & $(0.007)$ & $(0.008)$ & $(0.006)$ & $(0.002)$ & $(0.023)$ & $(0.003)$ & $(0.003)$ & $(0.017)$ & $(0.012)$ \\
\hline \multirow[t]{2}{*}{ D ebt to assets } & $-0.304 * * *$ & $-0.145 * * *$ & $-0.136 * * *$ & $0.026 * * *$ & $-0.006 * *$ & -0.011 & $0.015 * * *$ & -0.001 & & $-0.138 * * *$ \\
\hline & $(0.032)$ & $(0.009)$ & $(0.010)$ & $(0.007)$ & $(0.003)$ & $(0.033)$ & $(0.003)$ & $(0.003)$ & & $(0.016)$ \\
\hline \multirow[t]{2}{*}{ Cash to assets } & & & & $-0.022 * * *$ & $-0.007 * * *$ & $-0.171 * * *$ & $-0.020 * * *$ & $0.006 *$ & $-0.157 * * *$ & \\
\hline & & & & $(0.006)$ & $(0.003)$ & $(0.034)$ & $(0.002)$ & $(0.003)$ & $(0.018)$ & \\
\hline \multirow[t]{2}{*}{ Cash flow to assets } & & & & $0.044 * * *$ & 0.009 & $0.207 * * *$ & 0.005 & $-0.039 * * *$ & $-0.508 * * *$ & $0.052 * *$ \\
\hline & & & & $(0.011)$ & $(0.005)$ & $(0.055)$ & $(0.004)$ & $(0.005)$ & $(0.032)$ & $(0.026)$ \\
\hline \multirow[t]{2}{*}{ Tob in's a } & & & & $0.006 * * *$ & $0.003 * * *$ & 0.003 & -0.000 & $-0.001 * *$ & -0.001 & $0.015 * * *$ \\
\hline & & & & $(0.001)$ & $(0.000)$ & $(0.006)$ & $(0.000)$ & $(0.001)$ & $(0.002)$ & $(0.003)$ \\
\hline \multirow[t]{2}{*}{ Intercept } & $-0.706 * * *$ & -0.069 & $-0.421 * * *$ & $0.066 *$ & $-0.049 * * *$ & $-0.701 * * *$ & $-0.112 * * *$ & $0.084 * * *$ & $-1.540 * * *$ & $0.465 * * *$ \\
\hline & $(0.175)$ & $(0.064)$ & $(0.067)$ & $(0.036)$ & $(0.018)$ & $(0.236)$ & $(0.018)$ & $(0.032)$ & $(0.141)$ & $(0.115)$ \\
\hline Year dum m y & YES & YES & YES & YES & YES & YES & YES & YES & YES & YES \\
\hline Fim dum m y & YES & YES & YES & YES & YES & YES & YES & YES & YES & YES \\
\hline Observations & 15,456 & 15,456 & 15,448 & 15,322 & 15,322 & 15,299 & 15,299 & 9,689 & 15,322 & 15,322 \\
\hline$R$-squared & 0.053 & 0.111 & 0.117 & 0.058 & 0.129 & 0.027 & 0.031 & 0.049 & 0.231 & 0.068 \\
\hline Num ber of fim $\mathrm{s}$ & 1,982 & 1,982 & 1,982 & 1,964 & 1,964 & 1,964 & 1,964 & 1,252 & 1,964 & 1,964 \\
\hline
\end{tabular}

$* * * p<0.01, * * p<0.05, * p<0.1$ 
Panel B: Foreign institutional ownership

\begin{tabular}{|c|c|c|c|c|c|c|c|c|c|c|}
\hline \multirow[b]{2}{*}{ Variab les } & (1) & (2) & (3) & (4) & (5) & (6) & (7) & (8) & (9) & (10) \\
\hline & ROE & ROA & $\begin{array}{c}0 \text { perating } \\
\text { incom e to } \\
\text { sales }\end{array}$ & $\begin{array}{l}\text { Payout to } \\
\text { equity }\end{array}$ & $\begin{array}{l}\text { D ividend } \\
\text { to equ ity }\end{array}$ & $\begin{array}{c}\text { CAPEX to } \\
\text { fixed } \\
\text { assets }\end{array}$ & $\begin{array}{c}\text { A cqu is itio } \\
\mathrm{n} \text { to } \\
\text { assets }\end{array}$ & $\begin{array}{l}R \& D \text { to } \\
\text { sales }\end{array}$ & $\begin{array}{l}\text { Debt to } \\
\text { assets }\end{array}$ & $\begin{array}{l}\text { Cash to } \\
\text { assets }\end{array}$ \\
\hline \multirow[t]{2}{*}{ Fore ign institutional ow nersh ip } & -0.012 & 0.037 *** & $0.043 * * *$ & $0.026 * * *$ & $0.011 * * *$ & $0.156 * * *$ & 0.006 & 0.005 & $-0.217 * * *$ & $0.065 * * *$ \\
\hline & $(0.032)$ & $(0.013)$ & $(0.014)$ & $(0.010)$ & $(0.004)$ & $(0.046)$ & $(0.004)$ & $(0.003)$ & $(0.023)$ & $(0.020)$ \\
\hline Fore ign institu tiona low nersh ip & -0.001 & -0.010 & -0.005 & $0.021 * * *$ & $0.005 * *$ & $-0.087 * * *$ & 0.001 & 0.001 & 0.011 & -0.018 \\
\hline$\times$ JSC dum m y & $(0.015)$ & $(0.007)$ & $(0.008)$ & $(0.005)$ & $(0.002)$ & $(0.023)$ & $(0.002)$ & $(0.002)$ & $(0.014)$ & $(0.012)$ \\
\hline \multirow[t]{2}{*}{ JSC dum m y } & -0.006 & $-0.005 * * *$ & $-0.007 * * *$ & $-0.002 *$ & $-0.002 * * *$ & $0.030 * * *$ & -0.000 & -0.000 & $-0.040 * * *$ & 0.002 \\
\hline & $(0.004)$ & $(0.001)$ & $(0.002)$ & $(0.001)$ & $(0.000)$ & $(0.005)$ & $(0.000)$ & $(0.001)$ & $(0.003)$ & $(0.003)$ \\
\hline \multirow[t]{2}{*}{ LN (assets) } & $0.048 * * *$ & $0.010 * * *$ & $0.029 * * *$ & -0.003 & $0.004 * * *$ & $0.046 * * *$ & $0.006 * * *$ & $-0.003 *$ & $0.101 * * *$ & $-0.017 * * *$ \\
\hline & $(0.010)$ & $(0.004)$ & $(0.004)$ & $(0.002)$ & $(0.001)$ & $(0.013)$ & $(0.001)$ & $(0.002)$ & $(0.008)$ & $(0.006)$ \\
\hline \multirow[t]{2}{*}{ Fore ign sa les to total sales } & -0.019 & 0.011 & -0.003 & -0.003 & $-0.003 * *$ & 0.016 & $-0.005 *$ & 0.001 & 0.014 & \\
\hline & $(0.016)$ & $(0.007)$ & $(0.008)$ & $(0.006)$ & $(0.002)$ & $(0.023)$ & $(0.003)$ & $(0.003)$ & $(0.017)$ & \\
\hline \multirow[t]{2}{*}{ D ebt to assets } & $-0.309 * * *$ & $-0.147 * * *$ & $-0.138 * * *$ & $0.026 * * *$ & $-0.007 * *$ & -0.006 & $0.015 * * *$ & -0.001 & & $-0.134 * * *$ \\
\hline & $(0.032)$ & $(0.009)$ & $(0.010)$ & $(0.007)$ & $(0.003)$ & $(0.033)$ & $(0.003)$ & $(0.003)$ & & $(0.016)$ \\
\hline \multirow[t]{2}{*}{ Cash to assets } & & & & $-0.023 * * *$ & $-0.008 * * *$ & $-0.173 * * *$ & $-0.020 * * *$ & 0.005 & $-0.151 * * *$ & \\
\hline & & & & $(0.006)$ & $(0.003)$ & $(0.034)$ & $(0.002)$ & $(0.003)$ & $(0.018)$ & \\
\hline \multirow[t]{2}{*}{ Cash flow to assets } & & & & $0.047 * * *$ & $0.010 *$ & $0.210 * * *$ & 0.005 & $-0.039 * * *$ & $-0.514 * * *$ & $0.053 * *$ \\
\hline & & & & $(0.011)$ & $(0.005)$ & $(0.056)$ & $(0.004)$ & $(0.005)$ & $(0.032)$ & $(0.026)$ \\
\hline \multirow[t]{2}{*}{ Tob in's a } & & & & $0.006 * * *$ & $0.003 * * *$ & 0.003 & -0.000 & $-0.001 * *$ & -0.001 & $0.015 * * *$ \\
\hline & & & & $(0.001)$ & $(0.000)$ & $(0.006)$ & $(0.000)$ & $(0.001)$ & $(0.002)$ & $(0.003)$ \\
\hline \multirow[t]{2}{*}{ Intercept } & $-0.744 * * *$ & -0.095 & $-0.439 * * *$ & $0.067 *$ & $-0.054 * * *$ & $-0.702 * * *$ & $-0.109 * * *$ & $0.084 * * *$ & $-1.550 * * *$ & $0.487 * * *$ \\
\hline & $(0.174)$ & $(0.065)$ & $(0.067)$ & $(0.036)$ & $(0.018)$ & $(0.239)$ & $(0.018)$ & $(0.032)$ & $(0.141)$ & $(0.114)$ \\
\hline Year dum m y & YES & YES & YES & YES & YES & YES & YES & YES & YES & YES \\
\hline F im dum m y & YES & YES & YES & YES & YES & YES & YES & YES & YES & YES \\
\hline 0 bservations & 15,456 & 15,456 & 15,448 & 15,322 & 15,322 & 15,299 & 15,299 & 9,689 & 15,322 & 15,322 \\
\hline R-squared & 0.053 & 0.106 & 0.114 & 0.057 & 0.123 & 0.027 & 0.032 & 0.049 & 0.237 & 0.069 \\
\hline N um ber of fim $\mathrm{s}$ & 1,982 & 1,982 & 1,982 & 1,964 & 1,964 & 1,964 & 1,964 & 1,252 & 1,964 & 1,964 \\
\hline
\end{tabular}

-In parentheses are robust standard errors corrected for clustering at the firm level.

$* * * p<0.01, * * p<0.05, * p<0.1$ 
Figure 1: Board composition from 1997 to 2016

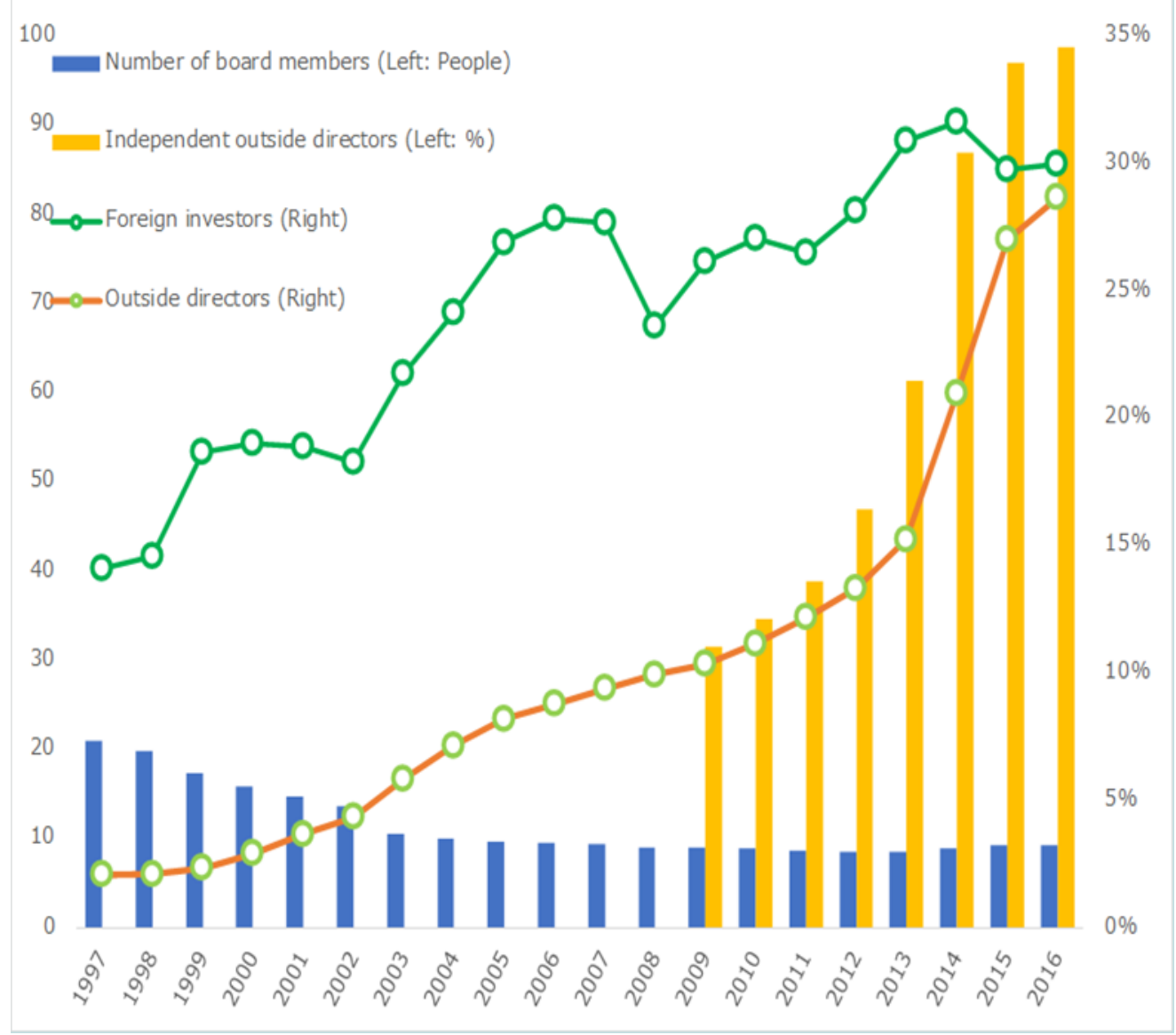


Figure 2: The Ownership Ratio of Insiders (Banks, Corporation, and Insurance Firms) from 1970 to 2017

Source: Based on the Survey of Shareholders, TSE.

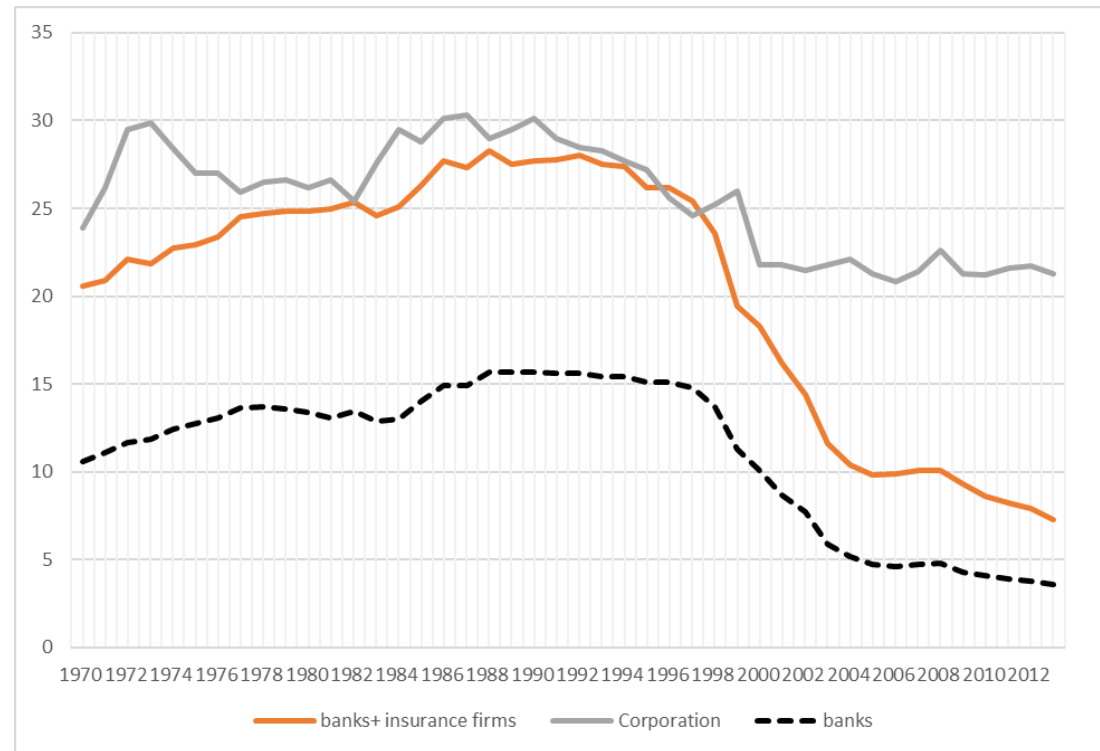

